\title{
ANALISIS FAKTOR-FAKTOR YANG MEMENGARUHI KEPATUHAN BENDAHARA PEMERINTAH DALAM PENYETORAN PAJAK
}

\author{
Marwanto Harjowiryono \\ Pusdiklat Anggaran dan Perbendaharaan \\ Alamat Korespondensi: marwantohw@yahoo.com
}

\begin{abstract}
Tax revenue is the main source of funding for national development. It contributes to nearly 80 percent of the government revenue. However shortfall in tax revenue repeatedly occurs despite The Ministry of Finance's effort in intensifying and extending tax revenue. The Ministry emphizes on tax compliance expecially from the local government. Tax revenue from APBN and $A P B D$ expenditure which is still quite minimal at around 8 percent (or about Rp. 86 trillion) of total tax revenue in 2015 and 2016, while taxes paid by local treasurers from APBD expenditure are only 3.6 percent. This study aims to analyze the factors that influence the compliance of the Local Government Treasurer in depositing tax revenue by referring to the Fritz Heider's Attribution Theory which has relevance in determining the factors that influence a person in decision making. This research was conducted by distributing questionnaires to the Local Treasurer covering the Java Island and using the Treasurer Tax-Compliance as the dependent variable and the independent variables consisting of the Taxation Knowledge, the Attitudes towards Tax Obligations, the Quality of Tax Services, the Ease of Tax Application, and the Role of the Directorate General of Treasury. The analytical method used is logistic regression. The results showed that all variables simultaneously affected the Local Government Treasurer Tax-Compliance. Partially, the Taxation Knowledge, the Attitudes towards Tax Obligations, the Quality of Tax Services and the Ease of Tax Application affect Tax Compliance of Local Government Treasurers.
\end{abstract}

\section{KATA KUNCI:}

Pajak, Bendahara Pemerintah, Teori Atribusi, Regresi Logistik

\begin{abstract}
ABSTRAK
Penerimaan pajak masih merupakan sumber pendanaan untuk pembangunan nasional yaitu 80 persen penerimaan negara berasal dari penerimaan pajak. Akan tetapi, shortfall penerimaan pajak masih membayangi setiap tahun di tengah usaha pemerintah c.q. Kementerian Keuangan melakukan intensifikasi dan ekstensifikasi penerimaan pajak. Dalam upaya intensifikasi penerimaan pajak, Menteri Keuangan secara khusus memberikan perhatian atas upaya untuk meningkatkan penerimaan pajak dengan menyoroti kepatuhan pajak bendahara pemerintah, khususnya pemerintah daerah yang masih belum tertib dalam melakukan penyetoran pajak. Indikasinya antara lain penerimaan pajak dari Belanja Anggaran Pendapatan dan Belanja Negara (APBN) serta Anggaran Pendapatan dan Belanja Daerah (APBD) masih cukup minim pada kisaran 8 persen (sekitar Rp86 triliun) dari total penerimaan pajak tahun 2015 dan 2016, sementara pajak yang dibayarkan oleh bendahara daerah dari belanja APBD hanya 3,6 persen. Penelitian ini bertujuan untuk menganalisis faktor-faktor yang memengaruhi kepatuhan bendahara pemerintah daerah dalam melakukan penyetoran penerimaan pajak dengan mengacu pada Teori Atribusi Fritz Heider yang memiliki relevansi dalam menemukan faktor-faktor yang memengaruhi seseorang dalam memilih suatu keputusan. Penelitian ini dilakukan dengan menyebarkan kuisioner terhadap bendahara pemerintah daerah lingkup Pulau Jawa dengan menggunakan kepatuhan pajak bendahara pemerintah sebagai variabel terikat dan variabel bebas terdiri dari pengetahuan perpajakan, sikap terhadap kewajiban perpajakan, kualitas pelayanan pajak, kemudahan aplikasi pajak, dan peran Direktorat Jenderal Perbendaharaan. Metode analisis yang digunakan adalah regresi logistik. Hasil penelitian menunjukkan bahwa secara simultan seluruh variabel berpengaruh terhadap kepatuhan pajak bendahara pemerintah daerah. Secara parsial, pengetahuan perpajakan, sikap terhadap kewajiban perpajakan, kualitas pelayanan pajak, dan kemudahan aplikasi pajak berpengaruh terhadap kepatuhan pajak bendahara pemerintah daerah.
\end{abstract}

\section{KLASIFIKASI JEL:}

E62

\section{CARA MENGUTIP:}

Harjowiryono, M. (2019). Analisis faktor-faktor yang memengaruhi kepatuhan bendahara pemerintah dalam penyetoran pajak. Indonesian Treasury Review: Jurnal Perbendaharaan, Keuangan Negara Dan Kebijakan Publik, 4(3),195-217. 


\section{PENDAHULUAN}

\subsection{Latar Belakang}

Pembangunan nasional merupakan upaya untuk mewujudkan tujuan nasional bangsa Indonesia yakni bangsa yang maju, mandiri, sejahtera, berkeadilan, berdasarkan iman dan takwa kepada Tuhan Yang Maha Kuasa. Dalam Undang-Undang Dasar (UUD) 1945 alinea keempat disebutkan bahwa hakikat tujuan pembangunan nasional adalah mencerdaskan kehidupan bangsa, menciptakan kesejahteraan umum, melindungi seluruh tumpah darah Indonesia, dan membantu melaksanakan ketertiban dunia dan perdamaian abadi. Agar pembangunan nasional dapat terlaksana dengan baik dan mampu mencapai tujuan pembangunan yang digariskan dalam UUD 1945 tersebut tentu saja pemerintah membutuhkan sumber pendanaaan yang besar.

Sumber pendanaan pembangunan terbesar selama ini berasal dari sektor pajak. Peran penerimaan pajak sebagai tulang punggung sumber pendanaan pembangunan tercermin antara lain dalam data I-Account Anggaran Pendapatan dan Belanja Negara (APBN). Berdasarkan data I-Account APBN terpublikasi per tanggal 28 Mei 2019, pada tahun anggaran 2018 penerimaan pajak mencapai Rp1.313,32 triliun atau 67,57 persen dari total pendapatan dan hibah APBN tahun anggaran 2018 dan berkontribusi sebesar 59,34 persen dalam membiayai belanja negara pada Tahun Anggaran 2018. Jumlah penerimaan pajak tersebut meningkat sebesar 14,10 persen dari penerimaan pajak tahun anggaran 2017. Dengan mempertimbangkan jumlah penerimaan dari sektor non pajak seperti penerimaan bea masuk, pungutan ekspor dan cukai, penerimaan negara bukan pajak (PNBP) serta hibah yang masih belum optimal, maka performa penerimaan dari sektor pajak akan sangat memengaruhi kinerja APBN serta kelancaran pembangunan nasional secara keseluruhan.

Kontribusi penerimaan pajak dalam APBN yang sangat dominan dari sisi persentase tersebut sebetulnya belum mencerminkan kinerja optimal Direktorat Jenderal Pajak (DJP) selaku otoritas pajak dalam menggali potensi penerimaan pajak. Kalangan pengamat ekonomi dan perpajakan mayoritas cenderung berpendapat bahwa potensi penerimaan pajak masih dapat digali lebih dalam. Danny Darussalam Tax Center (DDTC) yang rilis pada bulan April 2019 menyebutkan bahwa penerimaan pajak di Indonesia diperkirakan baru mencapai 50 persen dari potensi yang ada sehingga berakibat tax ratio menjadi tidak optimal. Berdasarkan penelitiannya, indikator tax effort atau rasio antara penerimaan pajak terhadap potensinya masih menempatkan angka tax effort Indonesia tahun 2018 baru mencapai 43 persen hingga 59 persen dari kapasitasnya. Dengan demikian terdapat 41 persen hingga 57 persen aktivitas ekonomi yang berpotensi terkena pajak namun belum dikenai pajak oleh pemerintah.

Tabel 1. Penerimaan Pajak Tahun 2004 s.d. 2018

\begin{tabular}{|c|c|c|c|c|c|}
\hline & & & & & \\
Tahun & $\begin{array}{c}\text { Penerima } \\
\text { an Pajak }\end{array}$ & $\begin{array}{c}\text { Pendapat } \\
\text { an } \\
\text { Hibah }\end{array}$ & $\begin{array}{c}\text { Pendapatan } \\
\text { APBN }\end{array}$ & $\begin{array}{c}\text { Belanja } \\
\text { Negara }\end{array}$ & $\begin{array}{c}\text { \% Belanja } \\
\text { Negara }\end{array}$ \\
\hline 2004 & 239 & 403 & 59,16 & 427 & 55,87 \\
\hline 2005 & 299 & 495 & 60,28 & 510 & 58,58 \\
\hline 2006 & 371 & 638 & 58,22 & 667 & 55,68 \\
\hline 2007 & 425 & 708 & 60,10 & 758 & 56,14 \\
\hline 2008 & 571 & 982 & 58,18 & 986 & 57,94 \\
\hline 2009 & 545 & 849 & 64,16 & 937 & 58,09 \\
\hline 2010 & 628 & 995 & 63,12 & 1.042 & 60,28 \\
\hline 2011 & 743 & 1.211 & 61,35 & 1.295 & 57,35 \\
\hline 2012 & 836 & 1.338 & 62,46 & 1.491 & 56,04 \\
\hline 2013 & 921 & 1.439 & 64,04 & 1.651 & 55,82 \\
\hline 2014 & 985 & 1.551 & 63,53 & 1.767 & 55,74 \\
\hline 2015 & 1.061 & 1.508 & 70,35 & 1.806 & 58,73 \\
\hline 2016 & 1.106 & 1.556 & 71,08 & 1.864 & 59,32 \\
\hline 2017 & 1.151 & 1.666 & 69,07 & 2.007 & 57,34 \\
\hline 2018 & 1.313 & 1.944 & 67,57 & 2.213 & 59,34 \\
\hline
\end{tabular}

(Sumber: I-Account APBN Tahun 2004-2018)

*) Di luar Cukai, Bea Masuk, dan Bea Keluar

Masih belum optimalnya kinerja penerimaan pajak selain dari sisi potensi penerimaan yang belum maksimal juga ditunjukkan dengan angka tax ratio yang masih relatif rendah dibandingkan negara lain. Ngadiman \& Huslin (2015) menyebutkan bahwa permasalahan rendahnya penerimaan pajak yang terus terjadi di Indonesia ditunjukkan dengan rendahnya rasio pajak terhadap Pendapatan Domestik Bruto (PDB) Indonesia yang berada pada kisaran angka 11 hingga 12,3 persen selama 2009-2012. Angka ini menurut Ngadiman \& Huslin (2015) relatif rendah jika dibandingkan dengan angka rata-rata tax ratio dunia, bahkan juga relatif rendah jika 
dibandingkan dengan rata-rata tax ratio negaranegara lingkup ASEAN. Danny Darussalam Tax Center (DDTC) yang rilis pada bulan April 2019 juga menyebutkan bahwa akibat dari penggalian potensi pajak yang tidak maksimal menyebabkan tax ratio di Indonesia baru mencapai 10,3 persen dari PDB atau masih di bawah rentang International Monetary Fund (IMF) yakni 12,75 persen hingga 15 persen.

Tabel 2. Tax Ratio Negara ASEAN Tahun 2011 s.d. 2017

\begin{tabular}{|c|c|c|c|c|}
\hline \multicolumn{1}{|c|}{ Tahun } & Indonesia & Singapura & Filipina & Thailand \\
\hline 2011 & 12,17 & 13,27 & N/A & 17,74 \\
\hline 2012 & 12,48 & 13,79 & 13,76 & 16,76 \\
\hline 2013 & 12,49 & 13,41 & 14,14 & 18,44 \\
\hline 2014 & 12,15 & 13,7 & 14,46 & 17,25 \\
\hline 2015 & 12,04 & 13,31 & 14,52 & 17,62 \\
\hline 2016 & 11,6 & 13,71 & 14,56 & 16,86 \\
\hline 2017 & 11,2 & 14,83 & 15,13 & 16,31 \\
\hline
\end{tabular}

(Sumber: Government Finance Statistic, 2019)

Dibandingkan dengan empat negara terkemuka lainnya di kawasan ASEAN yaitu Singapura, Malaysia, Filipina, dan Thailand, angka tax ratio Indonesia merupakan yang paling rendah. Berdasarkan Tabel 2, tax ratio Indonesia pada tahun 2016 dan 2017 cenderung mengalami penurunan.

Penyebab rendahnya angka tax ratio Indonesia tersebut menjadi perhatian berbagai pihak. Pusat Studi Ekonomi dan Perpajakan (PSEP) pada rilis bulan Maret 2019 mengidentifikasi tiga penyebab utama rendahnya angka tax ratio Indonesia yaitu masih rendahnya tingkat kepatuhan karena biaya kepatuhan wajib pajak yang masih cukup tinggi; kurangnya kepastian hukum dengan masih terjadinya kebijakan yang diterapkan secara inkonsisten seperti peraturan terkait pemungutan tarif jalan tol yang hanya berlaku tiga minggu kemudian dicabut; dan adanya peer country pressure yaitu kurang bersaingnya tarif pajak di Indonesia dibanding negara lain di ASEAN.

Pemerintah, dalam hal ini Kementerian Keuangan terus berupaya meningkatkan angka tax ratio dan penerimaan pajak dengan melakukan intensifikasi maupun ekstensifikasi pajak seperti melalui penyediaan aplikasi pajak online melalui fasilitas $e$-Billing dan $e$-Filing untuk memudahkan pembayaran dan pelaporan pajak, memudahkan pelaksanaan amnesti pajak untuk meluaskan basis wajib pajak, meningkatkan mutu pendataan potensi pajak baik dalam maupun luar negeri dan penegakan hukum perpajakan secara lebih tegas.

Selain beberapa strategi tersebut, salah satu sisi peluang untuk meningkatkan penerimaan pajak adalah dengan melakukan intensifikasi penerimaan pajak melalui bendahara pemerintah. Dalam pelaksanaan APBN dan APBD, bendahara pemerintah berperan sebagai pemungut dan penyetor pajak dari aktivitas belanja APBN dan APBD. Secara teoritis, dengan jumlah APBN dan APBD yang sangat besar dan terus meningkat setiap tahun maka jumlah pajak yang dipungut dan disetor oleh bendahara instansi pemerintah seharusnya juga semakin besar.

\subsection{Rumusan Masalah}

Subandi \& Fadhil (2018) menyebutkan hal yang kontradiktif masih terjadi terkait dengan pemungutan pajak yang berasal dari belanja APBN dan APBD. Meskipun belanja pada APBN dan APBD semakin besar namun pemungutan pajak dari belanja APBN dan APBD masih kecil. Bahkan Menteri Keuangan dalam Subandi \& Fadhil (2018) menyebutkan bahwa penerimaan pajak dari pelaksanaan APBN dan APBD masih tergolong kecil yaitu kurang dari 8 persen terhadap total penerimaan pajak tahun 2015 dan 2016. Menurut Menteri Keuangan, jika kewajiban perpajakan lingkup belanja APBN dan APBD dilakukan dengan benar oleh bendahara, maka jumlah penerimaannya akan jauh lebih besar dari penerimaan saat ini yang sekitar Rp86 triliun.

Masih rendahnya penerimaan pajak dari belanja APBN dan APBD menurut Menteri Keuangan antara lain disebabkan adanya kendala pada penyetoran dan pelaporan pajak oleh bendahara satuan kerja. Hal tersebut menurut Subandi \& Fadhil (2018) cukup kontradiktif dikarenakan seharusnya pengumpulan, penyetoran, dan pelaporan pajak oleh bendahara satuan kerja dapat dilakukan dengan lebih mudah karena bendahara satuan kerja merupakan bagian dari unsur pemerintah.

Menteri Keuangan dalam rilis bulan September 2017, kembali menyebutkan bahwa salah satu indikasi titik lemah dalam mengumpulkan pajak dari kegiatan APBN dan APBD adalah peranan bendahara pemerintah. Banyak bendahara pemerintah yang belum memahami transaksi keuangan khususnya terkait pemungutan pajak. Bahkan Menteri Keuangan tidak memungkiri adanya faktor kesengajaan yang membuat bendahara pemerintah tidak menyetorkan pajaknya. 
Padahal peran bendahara pemerintah sangat penting dalam rangka pengumpulan penerimaan pajak, baik yang berasal dari pusat maupun daerah. Menurut Menteri Keuangan, ketidakpahaman dan ketidakpatuhan bendahara pemerintah ini perlu diawasi oleh Aparat Pengawas Internal Pemerintah (APIP) dari setiap kementerian/lembaga/pemerintah daerah. Indikasi ketidakpatuhan bendahara pemerintah dalam menjalankan kewajiban perpajakan juga disebutkan oleh Kustiawan, Solikin \& Zulhaimi (2018). Badan Pemeriksa Keuangan (BPK) dalam Kustiawan, Solikin \& Zulhaimi (2018) menemukan permasalahan penyetoran pajak senilai Rp859,64 miliar dan sanksi senilai Rp13,69 miliar atas $11 \mathrm{~K} / \mathrm{L}, 9$ pemerintah provinsi dan 10 pemerintah kota/kabupaten. Tindakan tidak menyetor pajak yang dilakukan bendahara pemerintah tersebut dilakukan dalam bentuk setoran pajak fiktif dan/atau terlambat menyetor pajak sehingga menyebabkan keterlambatan pelimpahan pajak oleh bank persepsi. Sebagai contoh, terkait indikasi setoran fiktif oleh bendahara pemerintah, Badan Pemeriksa Keuangan (BPK) menemukan perbuatan melawan hukum yang dilakukan bendahara pemerintah senilai Rp674,6 juta. Bendahara pemerintah diduga memiliki Surat Setoran Pajak (SSP) fiktif berdasarkan hasil uji silang terhadap Modul Penerimaan Negara (MPN) dan konfirmasi ke Kantor Pelayanan Perbendaharaan Negara (KPPN) dan bank persepsi. BPK juga menemukan permasalahan keterlambatan penyampaian SPT dan adanya bendahara yang tidak menyampaikan SPT dengan potensi sanksi senilai Rp3,1 miliar.

Berdasarkan permasalahan tersebut, penelitian ini bermaksud untuk menganalisis faktor-faktor yang memengaruhi kepatuhan bendahara pemerintah dalam melakukan penyetoran penerimaan pajak. Penelitian ini berpijak pada pengembangan hasil penelitian terdahulu dalam topik sejenis dengan merumuskan variabel-variabel yang diduga berpengaruh terhadap kepatuhan bendahara pemerintah dalam melakukan penyetoran pajak, yaitu variabel pengetahuan perpajakan berdasarkan penelitian Hardiningsih \& Yulianawati (2011) serta Suyapto \& Lasmana (2014), variabel sikap terhadap kewajiban perpajakan berdasarkan penelitian Hardiningsih \& Yulianawati (2011), Suyapto \& Lasmana (2014) dan Subandi \& Fadhil (2018), variabel kualitas pelayanan perpajakan berdasarkan penelitian Hardiningsih \& Yulianawati (2011) dan Suyapto \& Lasmana (2014), variabel kemudahan aplikasi perpajakan berdasarkan penelitian Lee (2016), Purwidyasari \& Syafruddin (2017) serta Kustiawan, Solikin \& Zulhaimi (2018) variabel peran Direktorat Jenderal Perbendaharaan (DJPb).

Peran DJPb merupakan unsur kebaruan dari penelitian ini dimana dalam pelaksanaan APBN, DJPb melalui instansi vertikalnya di daerah yaitu KPPN yang bersinggungan langsung dengan bendahara pemerintah dalam pencairan APBN. Dengan posisi yang sangat strategis tersebut, $\mathrm{DJPb}$ dapat memiliki peran yang penting dalam melakukan pembinaaan ke bendahara pemerintah. Secara khusus, Menteri Keuangan dalam berbagai kesempatan Rapat Pimpinan Eselon I Kementerian Keuangan mengharapkan peran besar $\mathrm{DJPb}$ dalam membina bendahara pemerintah untuk meningkatkan kepatuhan bendahara pemerintah dalam penyetoran pajak.

\subsection{Penelitian Sebelumnya}

Dalam literatur terdahulu, terdapat beberapa penelitian baik yang terkait topik kepatuhan pajak wajib pajak secara umum maupun penelitian terkait kepatuhan pajak bendahara pemerintah dalam melakukan penyetoran pajak. Dharma \& Ariyanto (2014) melakukan penelitian terhadap Wajib Pajak Orang Pribadi (WPOP) lingkup Kantor Pelayanan Pajak Pratama Tigaraksa Tangerang dengan menggunakan kuisioner dan data sekunder. Hasil penelitian menyimpulkan bahwa variabel tingkat kesadaran membayar pajak, pemahaman wajib pajak terhadap manfaat pajak, pemahaman tentang sanksi pajak dan kualitas pelayanan fiskus secara simultan berpengaruh terhadap tingkat kepatuhan wajib pajak. Sedangkan secara parsial, terdapat pengaruh antara pemahaman sanksi pajak terhadap tingkat kepatuhan wajib pajak.

Terkait topik penelitian kepatuhan pajak bendahara pemerintah, Ratnafuri \& Herawati (2012) melakukan penelitian kepada bendaharawan Dinas Pendidikan Kabupaten Bangkalan. Metode penelitian kualitatif dengan menggunakan wawancara, observasi dan studi dokumentasi. Hasil penelitian menyimpulkan bahwa pelaksanaan pemotongan dan pemungutan pajak yang dilakukan Dinas Pendidikan Kabupaten Bangkalan belum optimal dan tidak sesuai dengan ketentuan pajak yang berlaku. Bentuk ketidaksesuaian tersebut antara lain berupa ketentuan tarif 2 persen dirubah menjadi 4 persen pada pemotongan PPh Pasal 23 atas imbalan jasa konsultan, jumlah penghasilan neto perhitungannya berubah dari 100 persen menjadi 95 persen; adanya persamaan pemotongan tarif untuk honorarium antara PNS 
yang memiliki Nomor Pokok Wajib Pajak (NPWP) dan yang tidak memiliki NPWP serta adanya penggelembungan nilai minimal yang ditetapkan untuk dasar pemungutan PPN.

Afni (2013) melakukan penelitian terhadap Wajib Pajak Bendaharawan Pengeluaran di Kabupaten Rokan Hilir dengan menggunakan metode survei kuisioner dengan jumlah 30 responden. Hasil penelitian menyimpulkan variabel Pengetahuan Perpajakan, Pelayanan Perpajakan dan Sanksi Pajak secara simultan maupun parsial berpengaruh terhadap Kepatuhan Perpajakan.

Kustiawan, Solikin \& Zulhaimi (2018) melakukan penelitian terhadap Bendaharawan Universitas Negeri Jakarta dengan menggunakan metode wawancara dan deskriptif analistik dengan pendekatan kualitatif. Hasil penelitian menyimpulkan Bendaharawan Pemerintah sudah berupaya semaksimal mungkin dalam memenuhi kewajiban perpajakannya terutama dalam pemotongan dan pemungutan pajak penghasilan namun upaya tersebut harus didukung oleh sistem informasi yang memadai dan terintegrasi di lingkungan perguruan tinggi sehingga memudahkan pemenuhan kewajiban perpajakan bendaharawan.

Subandi \& Fadhil (2018) melakukan penelitian terhadap Bendahara Desa di Kota Batu dengan menggunakan metode survei dengan kuisioner kepada 38 responden. Hasil penelitian menyimpulkan terdapat pengaruh antara Pengetahuan Pajak, Pelayanan Pajak dan Sanksi Pajak terhadap kepatuhan pajak Bendahara Desa di Kota Batu.

\section{TINJAUAN PUSTAKA}

\subsection{Konsep Pajak}

Adam Smith (1898:302) mendefinisikan pengertian pajak sebagai "a contribution from the citizens to support of the state" sedangkan Sommerfield (1983:1) mendefinisikan pajak sebagai "any nonpenal yet compulsory transfer of resources from the private to public sector, levied on the basis of predetermined criteria and without receipt of specific benefit of equal value in order to accomplish some of nation's economic and social objectives" (Setiyaji \& Amir, 2005). Prof. Dr. Rochmat Soemitro, S.H. yang dikutip dari buku Perpajakan karangan Prof. Mardiasmo (2011:1) mendefinisikan pajak sebagai iuran atau pungutan rakyat kepada pemerintah dengan berdasarkan Undang-Undang yang berlaku atau peralihan kekayaan dari sektor swasta kepada sektor publik yang dapat untuk dipaksakan serta yang langsung ditunjuk dan dipakai gunakan untuk membiayai pengeluaran umum.
Setiyaji \& Amir (2005) menarik kesimpulan bahwa pajak memiliki beberapa aspek dasar yaitu: pertama, pembayaran pajak harus berdasarkan ketentuan perundangundangan; kedua, sifatnya dapat dipaksakan; ketiga, tidak ada balas jasa secara langsung kepada pembayar pajak; keempat, pungutan pajak dilakukan oleh institusi negara secara resmi dan kelima, pajak digunakan untuk membiayai pengeluaran pemerintah bagi kepentingan masyarakat umum.

Terkait dengan asas pemungutan pajak, Stiglitz (2000) menyebutkan bahwa asas pemungutan pajak harus memperhatikan beberapa prinsip : pertama, economic efficiency yaitu pengenaan pajak tidak boleh mendistorsi kondisi perekonomian; kedua, administration simplicity yaitu adanya kesederhanaan proses administrasi dalam pemungutan pajak; ketiga, flexibility yaitu kebijakan pengenaan pajak dapat berubah-ubah sesuai dengan kondisi perekonomian; keempat, political responsibility yaitu pemungutan pajak dan hasilnya harus dapat dipertanggungjawabkan kepada masyarakat; dan kelima, fairness yaitu pengenaan pajak dikenakan secara adil baik secara vertikal maupun horizontal.

Musgrave \& Musgrave (1989) membagi fungsi pajak menjadi tiga fungsi utama yaitu:

a. Fungsi Alokasi

Pajak merupakan jenis sumber daya pemerintah dalam melakukan pelayanan kepada warga negara melalui penyediaan barang publik secara seimbang dengan komposisi sumber daya yang paling efisien.

b. Fungsi Distribusi

Pajak digunakan pemerintah dalam rangka melakukan penyesuaian terhadap distribusi pendapatan dan kekayaan masyarkat agar lebih merata melalui pengenaan sistem pajak yang progesif.

c. Fungsi Stabilisasi

Pajak merupakan salah satu alat kebijakan fiskal untuk dapat mengurangi pengangguran, menstabilkan harga, mengatasi kelangkaan produksi dan mengurangi tingkat inflasi.

Dalam literatur lainnya, Sukirno (2000) dan juga oleh Nurmantu (2005:30), Suandy (2008:13), Mardiasmo (2011:1-2) dan Resmi (2011:3) menyebutkan bahwa pajak memiliki dua fungsi yaitu:

a. Fungsi Budgetair

Pajak merupakan salah satu sumber penerimaan pemerintah untuk membiayai belanjanya.

b. Fungsi Regulerend 
Pajak sebagai alat untuk mengatur atau melaksanakan kebijakan pemerintah serta mencapai tujuan - tujuan tertentu. Dengan fungsi ini pemerintah dapat mengatur pertumbuhan ekonomi melalui kebijakan pajak.

Hubungan tarif pajak dengan pendapatan pemerintah ditunjukkan dengan Kurva Laffer. Kurva ini menggambarkan konsep dari elastisitas penghasilan kena pajak dimana penghasilan kena pajak berubah sesuai dengan perubahan tarif pajak.

\section{Grafik 1. Kurva Laffer}

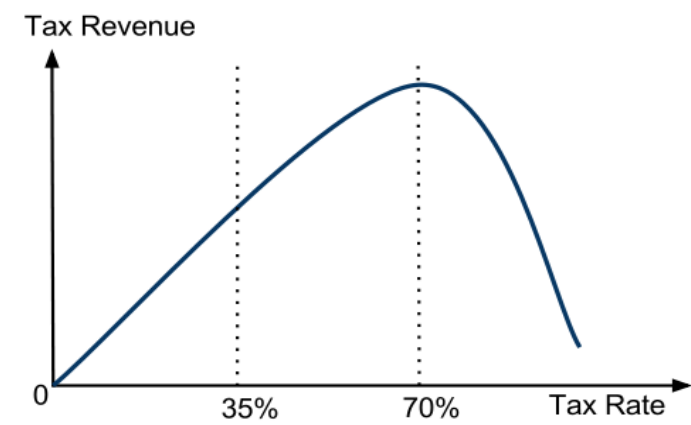

(Sumber: Tucker, 2010)

Kurva Laffer menjelaskan bahwa pajak penghasilan tidak akan naik pada tarif pajak ekstrim 0 persen dan 100 persen dan harus ada setidaknya satu tarif yang memaksimalkan pajak pendapatan pemerintah. Kurva Laffer ini biasanya direpresentasikan dalam bentuk sebuah grafik yang dimulai pada 0 persen pajak dengan nol pendapatan, naik ke tingkat maksimum pendapatan dengan tarif pajak menengah, dan kemudian jatuh kembali ke nol pendapatan dengan tarif pajak sebesar 100 persen.

Salah satu implikasi dari kurva Laffer adalah bahwa peningkatan tarif pajak yang melampaui titik tertentu akan menjadi kontraproduktif dalam meningkatkan penerimaan pajak bahkan pada titik paling ekstrim pendapatan pemerintah akan menjadi 0 ketika tarif pajak 100 persen dikarenakan masyarakat lebih memilih menghabiskan waktu dengan bersantai (leisure) daripada bekerja. Dengan demikian, dapat disimpulkan bahwa kebijakankebijakan yang diambil pemerintah misalnya terkait tarif akan memengaruhi perilaku masyarakat dalam melaksanakan kewajiban perpajakannya. Motivasi atau sebab seseorang dalam melakukan sebuah perilaku lazim dipelajari dalam konsep teori atribusi.

\subsection{Teori Atribusi}

Teori atribusi merupakan teori yang dikemukakan oleh Fritz Heider pada tahun 1958 dan kemudian dikembangkan oleh Harold Kelly pada tahun 1972 (Susherdianto, 2014). Atribusi adalah proses pembentukan kesan dari seseorang dimana dimana seseorang menarik kesimpulan tentang faktor-faktor yang memengaruhi perilaku orang lain. Teori atribusi mencoba untuk menemukan hal yang menyebabkan atau memotivasi seseorang untuk melakukan sesuatu (Kelley, 1973 dalam Kamil, 2015). Teori atribusi sangat relevan untuk menjelaskan faktor-faktor yang memengaruhi kepatuhan wajib pajak dalam mengambil keputusan (Susherdianto, 2014).

Teori atribusi ini relevan dalam pengembangan hipotesis penelitian ini. Dalam meneliti suatu fenomena, maka diperlukan pengetahuan lebih lanjut alasan seseorang ketika melakukan perbuatan tertentu. Begitu juga dengan perilaku yang kita tampilkan di hadapan orang lain. Dalam psikologi sosial, hal ini dinamakan dengan atribusi. Yang dimaksud dengan atribusi adalah proses dimana individu menjelaskan penyebab dari berbagai kejadian dan perilaku orang lain. Baron dan Byrne mendefinisikan atribusi adalah proses menyimpulkan motif, maksud, dan karakteristik orang lain dengan melihat pada perilakunya yang tampak (Rakhmat, 2001:93).

\subsection{Bendahara Pemerintah}

Dalam Undang-Undang Nomor 1 Tahun 2004 tentang Perbendaharaan Negara disebutkan pengertian bendahara adalah setiap orang atau badan yang diberi tugas untuk dan atas nama negara/daerah, menerima, menyimpan, dan membayar/menyerahkan uang atau surat berharga atau barang-barang negara/daerah.

Bendahara Penerimaan dan Bendahara Pengeluaran merupakan pejabat perbendaharaan yang secara fungsional bertanggung jawab kepada Kuasa Bendahara Umum Negara/Daerah dan secara pribadi bertanggung jawab atas seluruh pengurusan uang maupun surat berharga yang dikelolanya dalam rangka pelaksanaan APBN. Bendahara Pengeluaran Pembantu (BPP) bertanggung jawab secara pribadi atas uang yang berada dalam pengelolaannya dan wajib menyampaikan laporan pengelolaan dan pertanggungjawaban atas uang dalam pengelolaannya kepada Bendahara Pengeluaran. BPP dapat ditunjuk pada suatu satuan kerja jika memang dalam kondisi dibutuhkan.

Dalam pelaksanaan belanja APBN/APBD, Bendahara Pengeluaran dan BPP merupakan wajib pungut atas pajak yang timbul karena adanya pembayaran Uang Persediaan (UP). 
Bendahara Pengeluaran dan BPP harus menatausahakan uang dari kegiatannya sebagai wajib pungut dimaksud.

Bendahara Pengeluaran/BPP harus memperhitungkan dan memungut/memotong pajak atas pembayaran yang bersumber dari SPM Langsung (LS) Bendahara. Bendahara Pengeluaran/BPP harus menyetorkan pajak dimaksud ke Kas Negara menggunakan SSP/dokumen lain yang dipersamakan dengan SSP.

Dalam Undang-undang Nomor 28 Tahun 2007 tentang Ketentuan Umum Perpajakan (KUP), jenis pajak yang dipotong/dipungut Bendahara Pemerintah meliputi :

a. PPh Pasal 21, yaitu pemotongan atas penghasilan yg dibayarkan kepada orang pribadi sehubungan dengan pekerjaan, jabatan, jasa, dan kegiatan;

b. PPh Pasal 22, yaitu pemungutan atas penghasilan yg dibayarkan sehubungan dengan pembelian barang;

c. PPh Pasal 23, yaitu pemotongan atas penghasilan yg dibayarkan berupa hadiah, bunga, deviden, sewa, royalti, dan jasa-jasa lainnya selain Objek PPh Pasal 21;

d. PPh Pasal 4 (2), yaitu pemotongan atas penghasilan yang dibayarkan sehubungan jasa tertentu dan sumber tertentu (jasa konstruksi, sewa tanah/bangunan, pengalihan hak atas tanah/bangunan, hadiah undian, dan lainnya);

e. PPN, yaitu pemungutan atas pajak konsumsi yang dibayar sendiri sehubungan penyerahan Barang Kena Pajak dan Jasa Kena Pajak;

f. Bea Materei, yaitu pembayaran atas pemanfaatan dokumen-dokumen tertentu (kuitansi, kontrak).

Surat Pemberitahuan (SPT) berfungsi sebagai sarana bagi wajib pajak Bendahara Pemerintah dalam melaporkan dan mempertanggungjawabkan penghitungan jumlah pajak terutang. Secara umum SPT terdiri dari beberapa jenis yaitu:

a. SPT Masa

SPT Masa adalah SPT yang digunakan untuk melakukan pelaporan atas pembayaran Pajak bulanan. Terdapat beberapa jenis pajak yang dilaporkan dalam SPT Masa yaitu PPh Pasal 21, PPh Pasal 22, PPh Pasal 23, PPh Pasal 25, PPh Pasal 26, PPh Pasal 4 (2), PPh Pasal 15, PPN dan PPnBM, serta Pemungut PPN.

b. SPT Tahunan

SPT Tahunan adalah SPT yang digunakan untuk pelaporan tahunan. Terdapat beberapa jenis SPT Tahunan yaitu
SPT Wajib Pajak Badan dan SPT Wajib Pajak Orang Pribadi.

Bendahara dalam pelaporannya hanya membuat SPT Masa. Dalam melakukan penyetoran dan pelaporan pajak dalam SPT Masa, bendahara dibatasi tenggat waktu yang diatur sebagai berikut:

Tabel 3. Batas Waktu Penyetoran dan Pelaporan Pajak Bulanan

\begin{tabular}{|c|l|l|l|}
\hline No & \begin{tabular}{|} 
Jenis SPT \\
Masa
\end{tabular} & $\begin{array}{l}\text { Batas Waktu } \\
\text { Pembayaran }\end{array}$ & $\begin{array}{l}\text { Batas Waktu } \\
\text { Pelaporan }\end{array}$ \\
\hline 1. & $\begin{array}{l}\text { PPh Pasal 4 } \\
\text { ayat (2) }\end{array}$ & $\begin{array}{l}\text { Tgl. 10 bulan } \\
\text { berikut }\end{array}$ & $\begin{array}{l}\text { Tgl. 20 bulan } \\
\text { berikut }\end{array}$ \\
\hline 2. & $\begin{array}{l}\text { PPh Pasal } \\
21 / 26\end{array}$ & $\begin{array}{l}\text { Tgl. 10 bulan } \\
\text { berikut }\end{array}$ & $\begin{array}{l}\text { Tgl. 20 bulan } \\
\text { berikut }\end{array}$ \\
\hline 3. & $\begin{array}{l}\text { PPh Pasal } \\
23 / 26\end{array}$ & $\begin{array}{l}\text { Tgl. 10 bulan } \\
\text { berikut }\end{array}$ & $\begin{array}{l}\text { Tgl. 20 bulan } \\
\text { berikut }\end{array}$ \\
\hline 4. & PPh Pasal 22 & $\begin{array}{l}\text { Hari yang } \\
\text { sama saat } \\
\text { penyerahan } \\
\text { barang }\end{array}$ & $\begin{array}{l}\text { Tgl. 14 bulan } \\
\text { berikut }\end{array}$ \\
\hline 5. & $\begin{array}{l}\text { PPN dan PPn } \\
\text { BM }\end{array}$ & $\begin{array}{l}\text { Tgl. 7 bulan } \\
\text { berikut }\end{array}$ & $\begin{array}{l}\text { Tgl. 14 bulan } \\
\text { berikut }\end{array}$ \\
\hline
\end{tabular}

(Sumber: Undang-undang Nomor 28 Tahun 2007 tentang KUP)

Keterlambatan pelaporan untuk SPT Masa PPN dikenakan denda sebesar Rp500.000,00 (lima ratus ribu rupiah) dan untuk SPT Masa lainnya dikenakan denda sebesar Rp100.000,00 (seratus ribu rupiah). Sedangkan untuk keterlambatan SPT Tahunan PPh Orang Pribadi khususnya mulai Tahun Pajak 2008 dikenakan denda sebesar Rp100.000,00 (seratus ribu rupiah), dan SPT Tahunan PPh Badan dikenakan denda sebesar Rp1.000.000,00 (satu juta rupiah).

\subsection{Kepatuhan Pajak}

Kepatuhan Pajak dapat diartikan sebagai kesadaran wajib pajak dalam melaksanakan kewajiban perpajakannya sesuai peraturan perundang-undangan perpajakan secara baik dan benar (Subandi \& Fadhil, 2018). Menurut James \& Alley (2002) dalam Saad (2014) kepatuhan pajak mengacu pada kesediaan individu untuk bertindak sesuai peraturan perundang-undangan dan administrasi perpajakan tanpa diperlukan adanya penegakan hokum dari otoritas pajak. Dengan demikian, Kepatuhan Pajak Bendahara Pemerintah dapat didefinisikan sebagai kesadaran Bendahara Pemerintah dalam melaksanakan kewajiban perpajakannya sesuai peraturan perpajakan secara baik dan benar.

Pada PMK Nomor 192/PMK.03/2007 disebutkan kriteria wajib pajak tertentu yang disamakan sebagai wajib pajak patuh yaitu: 
pertama, tepat waktu dalam menyampaikan surat pemberitahuan; kedua, tidak mempunyai tunggakan pajak untuk semua jenis pajak; ketiga, tidak pernah dipidana dalam lima tahun terakhir dan keempat, melakukan kewajiban perpajakan secara sukarela sesuai dengan peraturan perpajakan yang berlaku di Indonesia.

\subsection{Pengetahuan Perpajakan}

Kamil (2015) mendefiniskan Pengetahuan Perpajakan sebagai penalaran dan pemaknaan dari pemahaman atas peraturan perundangundangan perpajakan. Menurut Hardiningsih \& Yulianawati (2011), peningkatan pengetahuan peraturan perpajakan masyarakat melalui pendidikan formal maupun non formal akan berdampak positif terhadap kesadaran wajib pajak untuk membayar pajak.

Saad (2014) menyebutkan bahwa dengan sistem perpajakan yang berlaku di Indonesia bertumpu pada kemampuan dari setiap wajib pajak (self assessment system), maka Pengetahuan Perpajakan merupakan hal yang sangat penting untuk menentukan apakah kewajiban pajak dilakukan secara akurat atau tidak. Dengan tingkat pengetahuan dan pemahaman tentang peraturan pajak yang memadai, masyarakat akan berpikiran terbuka dan positif bahwa pajak adalah murni digunakan untuk kebutuhan bangsa dan manfaatnya akan dikembalikan lagi sebesar-besarnya bagi seluruh masyarakat. Dengan tingkat pengetahuan dan pemahaman pajak yang memadai diharapkan tingkat kepatuhan wajib pajak untuk membayar pajak akan meningkat.

\subsection{Sikap Terhadap Kewajiban Perpajakan}

Robbins (2007) mendefinisikan sikap sebagai pernyataan evaluatif terhadap objek, orang atau peristiwa dimana hal tersebut mencerminkan perasaan seseorang terhadap sesuatu. Breckler (1984) menyebutkan sikap mempunyai tiga komponen utama yaitu kesadaran, perasaan dan perilaku dalam melaksanakan suatu kewajiban. Hardiningsih \& Yulianawati (2011) mendefinisikan sikap wajib pajak sebagai kesadaran dan keadaan mengetahui atau mengerti dari wajib pajak dalam melaksanakan kewajiban perpajakannya. Dengan demikian Sikap Terhadap Kewajiban Perpajakan merupakan kesadaran, perasaan dan perilaku seseorang dalam melaksanakan kewajiban-kewajiban perpajakannya.

Kewajiban Perpajakan Bendahara Pemerintah meliputi lingkup pelaksaanaan APBN dan APBD. Dalam lingkup pelaksanaan APBN, setiap Pengguna Anggaran (PA)/Kuasa Pengguna Anggaran (KPA) dan/atau Bendahara yang melakukan pembayaran atas beban APBN ditetapkan sebagai wajib pungut pajak sesuai dengan ketentuan Peraturan Perundangundangan (Pasal 47 Ayat 1 Peraturan Pemerintah Nomor 45 Tahun 2013 tentang Tata Cara Pelaksanaan Anggaran Pendapatan dan Belanja Negara). Dalam lingkup pelaksanaan APBD, Bendahara pengeluaran sebagai wajib pungut Pajak Penghasilan (PPh) dan pajak lainnya, wajib menyetorkan seluruh penerimaan potongan dan pajak yang dipungutnya ke rekening Kas Negara pada bank pemerintah atau bank lain yang ditetapkan Menteri Keuangan sebagai bank persepsi atau pos giro dalam jangka waktu sesuai ketentuan perundang-undangan (Pasal 64 Peraturan Pemerintah Nomor 58 Tahun 2005 tentang Pengelolaan Keuangan Daerah).

Secara umum proses bisnis kewajiban bendahara pemerintah meliputi tiga hal yaitu: pertama, melakukan pendaftaran/update data; kedua, melakukan pemotongan/pemungutan pajak; dan ketiga, melaporkannya dalam SPT Masa.

\subsection{Kualitas Pelayanan Perpajakan}

Hardiningsih dan Yulianawati (2011) menyebutkan definisi kualitas adalah suatu kondisi dinamis yang berhubungan dengan produk, jasa manusia, proses, dan lingkungan yang memenuhi atau melebihi harapan pihak yang menginginkannya. Menurut Fuadi dan Mangoting (2013), Pelayanan Pajak merupakan faktor eksternal yang dapat memengaruhi tingkat kepatuhan wajib pajak dalam melaksanakan kewajiban perpajakannya. Fuadi dan Mangoting (2013) mendefinisikan Kualitas Pelayanan sebagai bentuk pelayanan yang dapat memberikan kepuasan kepada pelanggan dan tetap dalam batas memenuhi standar pelayanan yang dapat dipertangggungjawabkan serta harus dilakukan secara terus-menerus. Dengan demikian Kualitas Pelayanan Perpajakan adalah pelayanan yang dapat memberikan kepuasan kepada wajib pajak dan tetap dalam batas memenuhi standar pelayanan yang dapat dipertangggungjawabkan serta harus dilakukan secara terus-menerus.

Susherdianto (2014) menyebutkan bahwa pemerintah dalam hal ini otoritas pajak harus menjalankan fungsi pelayanan dengan baik untuk meningkatkan kepatuhan dari wajib pajak agar penerimaan pajak bisa terus ditingkatkan. Dalam memberikan pelayanan terbaik yang harus dilakukan adalah mengetahui kewajiban dan haknya dalam menjalankan tugas sebagai aparatur pajak. 


\subsection{Kemudahan Aplikasi Perpajakan}

Penggunaan aplikasi merupakan bentuk dari kemajuan teknologi informasi. Williams \& Sawyer (2007) dalam Sigit (2019) mendefinisikan teknologi informasi sebagai bentuk teknologi dan semua pengembangannya yang dapat membantu manusia dalam membuat, mengubah, menyimpan, mengkomunikasikan dan atau menyebarkan informasi. Lienert (2009) dalam Sigit (2019) menyebutkan bahwa semakin kompleks suatu informasi yang diproses maka semakin besar kebutuhan sistem aplikasi yang berkualitas tinggi. Dengan demikian, Kemudahan Aplikasi Perpajakan adalah penggunaan aplikasi yang berkualitas tinggi sehingga memudahkan wajib pajak untuk melaksanakan kewajiban perpajakannya.

Dari beberapa studi literatur, implementasi penggunaan teknologi/aplikasi di beberapa negara dalam sistem pembayaran pajak dapat memengaruhi tingkat kepatuhan wajib pajak. Yilmaz dan Coolidge (2013) menganalisis efek dari penerapan e-Filing terhadap biaya kepatuhan pajak di negaranegara berkembang dan menunjukkan bahwa penerapan e-Filing dapat meningkatkan kepatuhan wajib pajak. Namun, jika implementasi $e$-Filing tidak dikelola secara tepat menurut Yilmaz dan Coolidge (2013) misalnya dengan masih mengharuskan wajib pajak untuk melaporkan pajak e-Filing dan secara paper/fisik menyebabkan meningkatnya biaya kepatuhan pajak secara keseluruhan. Bird and Oldman (2000) dengan konteks negara Singapura menyebutkan bahwa Singapura berhasil menerapkan integrasi dan komputerisasi administrasi pajak bukan hanya dengan memperkenalkan teknologi baru pada sistem administrasi pajaknya tetapi juga dengan melakukan rekayasa ulang sistem administrasi pajak sehingga meningkatkan layanan wajib pajak dan kepatuhan. Price Waterhouse Coopers (2010) mempresentasikan mandatory einvoicing secara elektronik sebagai salah satu metode alternatif pengumpulan PPN kepada Komisi Eropa dan menunjukkan bahwa dengan metode tersebut otoritas pajak mendapatkan akses informasi tentang transaksi penjualan pada tahap yang sangat awal yaitu pada saat faktur dibuat.

Dalam konteks sistem pajak di Indonesia, DJP mengembangkan sistem aplikasi yang dipergunakan oleh wajib pajak mulai dari pembayaran dan penyetoran sampai dengan pelaporan pajak.

\section{a. Pembayaran dan Penyetoran Pajak}

Pembayaran dan penyetoran pajak dilakukan langsung ke kas negara melalui dua cara yaitu secara elektronik/online dan melalui layanan pada loket/teller (over the counter) pada pada Bank Persepsi/Pos Persepsi/Bank Devisa Persepsi/Bank Persepsi Mata Uang Asing.

Pembayaran pajak secara online merupakan usaha pemerintah untuk memudahkan wajib pajak dalam membayar pajak. Sistem pembayaran pajak secara online dilakukan dengan menggunakan e-Billing. Sistem e-Billing merupakan metode pembayaran pajak secara elektronik dengan menggunakan kode billing atau ID-Billing. Billing System adalah sistem yang menerbitkan kode billing untuk pembayaran atau penyetoran penerimaan negara secara elektronik, tanpa perlu membuat Surat Setoran (SSP, SSBP, SSPB) manual.

Sistem e-Billing berbasis sistem Modul Penerimaan Negara (MPN) yang dikembangkan oleh $\mathrm{DJPb}$ untuk memfasilitasi wajib pajak membayarkan pajaknya dengan lebih mudah, lebih cepat dan lebih akurat. Pengembangan MPN diarahkan pada penyediaan fleksibilitas lebih bagi wajib pajak/ bayar. Sistem MPN yang saat ini sudah pada fase pengembangan generasi ketiga (MPN G-3) membuat wajib pajak/bayar dapat melakukan pengisian billing secara mandiri melalui portal yang disediakan secara online. Pembayaran atas billing dapat dilakukan melalui berbagai channel pembayaran secara elektronik seperti ATM, e-Banking, Kartu Debit/Kartu Kredit dan Phone Banking.

Dengan menggunakan e-Billing, wajib pajak akan memperoleh banyak manfaat, antara lain kemudahan membayar pajak dengan membuat ID-Billing di mana saja dan kapan saja, menghindari terjadinya kesalahan pencatatan transaksi yang masih sering terjadi jika pembayaran dilakukan secara manual dan transaksi dilakukan secara real time dimana data dan hasil transaksi akan langsung tersimpan di sistem DJP.

b. Aplikasi Pelaporan Pajak

Selain dilakukan secara manual di Kantor Pelayanan Pajak (KPP), pelaporan pajak saat ini sudah difasilitasi secara online melalui aplikasi e-Filling. Aplikasi e-Filing adalah suatu cara penyampaian Surat Pemberitahuan (SPT) secara elektronik yang dilakukan secara online dan real time melalui internet pada website DJP (http://www.pajak.go.id) atau Penyedia Layanan SPT Elektronik atau Application 
Service Provider (ASP). Layanan e-Filling melalui website DJP telah terintegrasi dalam layanan DJP Online. Bagi wajib pajak yang hendak menyampaikan laporan SPT Tahunan PPh Orang Pribadi maupun SPT Tahunan PPh Badan dapat mengisi dan menyampaikan laporan SPT-nya pada aplikasi e-Filing pada laman DJP Online.

\subsection{Peran Direktorat Jenderal Perbendaharaan (DJPb)}

Komarudin (1994:768) mendefinisikan peran sebagai tindakan yang dilakukan orang atau sekelompok orang dalam suatu peristiwa. Konsep tentang peran menurut Komarudin (1994:768) meliputi aspek tugas utama yang harus dilakukan oleh suatu manajemen, bagian suatu fungsi seseorang dalam kelompok atau pranata dan pola perilaku yang diharapkan dapat menyertai pelaksanaan suatu fungsi atau tugas. Peran yang ideal menurut Soekanto (2002:24), dapat didefinisikan sebagai peran yang dilakukan dengan baik oleh pemegang peranan tersebut.

Direktorat Jenderal Perbendaharaan (DJPb) merupakan unit Eselon I di bawah Kementerian Keuangan. Dalam Peraturan Menteri Keuangan (PMK) Nomor 234 /PMK.01/2015 tentang Organisasi dan Tata Kerja Kementerian Keuangan, DJPb memiliki tugas dan fungsi menyelenggarakan perumusan dan pelaksanaan kebijakan di bidang pelaksanaan anggaran, pengelolaan kas dan investasi, pembinaan pengelolaan keuangan Badan Layanan Umum, dan akuntansi dan pelaporan keuangan pemerintah sesuai dengan ketentuan peraturan perundang-undangan

Berdasarkan tugas dan fungsi tersebut, $\mathrm{DJPb}$ memang tidak memiliki peran secara langsung dalam pelaksanaan tugas terkait kewajiban perpajakan Bendahara Pemerintah. Namun, DJPb memiliki peran strategis selaku pembina Bendahara Satuan Kerja terkait dengan pelaksanaan APBN. Hal tersebut tertuang dalam PMK Nomor 262/PMK.01 /2016 Tentang Organisasi dan Tata Kerja Instansi Vertikal Direktorat Jenderal Perbendaharaan dimana disebutkan bahwa fungsi dari Bidang Supervisi KPPN dan Kepatuhan Internal pada Kanwil DJPb dan Seksi Manajemen Satker dan Kepatuhan Internal pada KPPN selaku unit vertikal DJPb di daerah adalah melakukan pembinaan pertanggungjawaban bendahara.

Dengan demikian, secara kultur DJPb memiliki hubungan dan interaksi yang erat dengan Bendahara Pemerintah. Dengan bentuk kewenangan dan interaksi erat yang dimilikinya tersebut maka DJPb diharapkan dapat memiliki peran penting dalam turut mengatasi permasalahan kepatuhan Bendahara Pemerintah dalam menyetorkan penerimaan pajaknya. Dengan adanya interaksi erat antara KPPN dengan bendahara, DJPb c.q. KPPN dapat menjadi figur pembina bagi bendahara termasuk dalam kaitan pelaksanaan kewajiban perpajakan bendahara. DJPb juga menjadi penanggungjawab pelaksanaan sertifikasi bagi Bendahara Satker Pusat. Sertifikasi Bendahara merupakan amanat dari Peraturan Pemerintah Nomor 45 Tahun 2013 tentang Tata Cara Pelaksanaan Anggaran Pendapatan dan Belanja Negara dimana pejabat/pegawai yang akan diangkat sebagai Bendahara Penerimaan atau Bendahara Pengeluaran harus memiliki Sertifikat Bendahara yang diterbitkan oleh Menteri Keuangan atau pejabat yang ditunjuk.

Digunakannya Peran DJPb sebagai variabel dalam penelitian ini juga didasari kewenangan $\mathrm{DJPb}$ sebagai regulator sistem penerimaan ke kas negara sebagaimana diatur dalam PMK Nomor 234 /PMK.01/2015 pasal 941. DJPb mengembangkan konsep Modul Penerimaan Negara (MPN) sebagai bentuk modernisasi pengelolaan perbendaharaan negara untuk menjalankan salah satu fungsi treasury yaitu menghimpun seluruh penerimaan negara. Saat ini fase pengembangan MPN sudah mencapai MPN Generasi Ketiga (MPN G-3) dengan berbagai kemudahan layanan penerimaan negara secara elektronik yang semakin berkembang dibandingkan MPN G-1 dan MPN G-2 sebelumnya.

Dalam sistem MPN, DJPb menjalankan fungsi Bendahara Umum Negara (BUN) sebagai mediator atas berbagai pihak seperti bank/pos persepsi, biller dan wajib pajak/bayar. Penerimaan negara yang disetor melalui bank/pos persepsi diikat dengan suatu kontrak yang mengatur kewajiban pihak bank/pos untuk menyediakan mekanisme layanan pembayaran termasuk pelaporannya dan hak atas fee dari layanan tersebut (www.djpb.kemenkeu.go.id).

Namun sistem MPN yang dikembangkan $\mathrm{DJPb}$ tersebut tentu membutuhkan kerja sama dan kepatuhan dari wajib setor termasuk dalam hal ini Bendahara Satker Pusat maupun Bendahara Pemda dalam melakukan penyetoran penerimaan negara. Oleh karena itu selaku regulator sistem penerimaan negara dan pengelola kas negara, $\mathrm{DJPb}$ juga sangat berkepentingan terhadap kepatuhan Bendahara Pemerintah dalam melakukan penyetoran penerimaan pajaknya.

Selain dua faktor di atas, penggunaan variabel Peran $\mathrm{DJPb}$ juga didasarkan adanya perintah Menteri Keuangan kepada penulis 
sewaktu menjabat sebagai Direktur Jenderal Perbendaharaan (2013-2019) dalam berbagai forum rapat pimpinan tingkat Kementerian Keuangan yang menugaskan kepada $\mathrm{DJPb}$ agar melakukan koordinasi dengan Pemda untuk memastikan seluruh Bendahara Pemda melakukan kewajiban perpajakan dengan benar. Perintah tersebut menjadi motivasi bagi penulis untuk meneliti peran yang dapat dilaksanakan oleh $\mathrm{DJPb}$ terkait dengan permasalahan kewajiban perpajakan Bendahara Pemda dan diharapkan nantinya dapat diberikan rekomendasi yang konstruktif terhadap tugas yang diamanahkan Menteri Keuangan tersebut.

Dengan demikian berdasarkan uraian di atas, variabel Peran DJPb dapat didefinisikan sebagai bentuk aktivitas yang dilaksanakan oleh $\mathrm{DJPb}$ dalam rangka melakukan pembinaan kepada Bendahara Pemerintah untuk meningkatkan kepatuhan dalam memenuhi kewajiban perpajakannya.

\subsection{Kerangka Penelitian}

Dalam penelitian ini penulis menggunakan variabel bebas yang terdiri dari Pengetahuan Perpajakan, Sikap Terhadap Kewajiban Perpajakan, Kualitas Pelayanan Perpajakan, Kemudahan Aplikasi Perpajakan dan Peran DJPb dan variabel terikat Kepatuhan Pajak Bendahara Pemda yang berdasarkan penelitian Subandi \& Fadhil (2018) memiliki tingkat kepatuhan pajak lebih rendah dibandingkan Bendahara Pemerintah Pusat. Penulis ingin menganalisis pengaruh dan hubungan antara variabel bebas secara simultan maupun secara parsial terhadap variabel terikat. Berdasarkan studi literatur terdahulu, seluruh variabel bebas diduga memiliki pengaruh positif terhadap variabel terikat. Berdasarkan hal tersebut, pengembangan hipotesis dapat digambarkan dalam skema berikut ini :

\section{Grafik 2. Kerangka Penelitian}

\begin{tabular}{|c|c|c|}
\hline Pengetahuan & + & \\
\hline Sikap Terhadap & + & \\
\hline $\begin{array}{l}\text { Kualitas } \\
\text { Pelavanan }\end{array}$ & + & $\begin{array}{l}\text { Kepatuhan Pajak } \\
\text { Bendahara Pemda }\end{array}$ \\
\hline Kemudahan & + & \\
\hline Peran DJPB & + & \\
\hline
\end{tabular}

(Sumber: data diolah)

\subsection{Hipotesis Penelitian}

Penelitian ini dilakukan dengan pengembangan hipotesis secara umum diduga Pengetahuan Perpajakan, Sikap Terhadap Kewajiban Perpajakan, Kualitas Pelayanan Perpajakan, Kemudahan Aplikasi Perpajakan dan Peran DJPb secara bersama-sama memiliki pengaruh terhadap Kepatuhan Pajak Bendahara Pemda dengan hipotesis secara parsialnya sebagai berikut:

H1 : Diduga Pengetahuan Perpajakan berpengaruh positif terhadap Kepatuhan Pajak Bendahara Pemda.

H2 : Diduga Sikap Terhadap Kewajiban Perpajakan berpengaruh positif terhadap Kepatuhan Pajak Bendahara Pemda.

H3 : Diduga Kualitas Pelayanan Perpajakan berpengaruh positif terhadap Kepatuhan Pajak Bendahara Pemda.

H4 : Diduga Kemudahan Aplikasi Perpajakan berpengaruh positif terhadap Kepatuhan Pajak Bendahara Pemda.

H5 : Diduga Peran DJPb berpengaruh positif terhadap Kepatuhan Pajak Bendahara Pemda.

\section{METODE PENELITIAN}

\subsection{Jenis Penelitian}

Jenis penelitian ini adalah penelitian kuantitatif deskriptif dengan menggunakan data primer dan data sekunder. Penelitian kuantitatif adalah suatu proses menemukan pengetahuan yang menggunakan data berupa angka sebagai alat menganalisis keterangan mengenai apa yang ingin diketahui (Kasiram, 2008:149).

\subsection{Jenis dan Sumber Data}

Jenis data yang digunakan dalam penelitian ini adalah data primer dan data sekunder. Data primer dalam penelitian ini adalah data kuisioner. Data kuisioner yang digunakan terdiri dari data interval terkait persepsi Bendahara Pemda terhadap indikator-indikator dari variabel bebas dan variabel terikat dimana data tersebut merupakan data kualitatif yang akan dikuantisir dengan skala likerts. Persepsi akan dikelompokkan menjadi lima yaitu Sangat Setuju, Setuju, Netral, Tidak Setuju dan Sangat Tidak Setuju dengan nilai 5, 4, 3, 2 dan 1 . Total indikator dalam kuisioner berjumlah 44 indikator. Penyebaran kuisioner akan dilakukan secara online kepada responden penelitian. 


Tabel 4. Jumlah Indikator Per Variabel
\begin{tabular}{|c|l|c|}
\hline No & \multicolumn{1}{|c|}{ Variabel } & Jumlah \\
\hline 1 & Pengetahuan Perpajakan & 10 \\
\hline 2 & $\begin{array}{l}\text { Sikap terhadap Kewajiban } \\
\text { Perpajakan }\end{array}$ & 10 \\
\hline 3 & Kualitas Pelayanan Perpajakan & 7 \\
\hline 4 & Kemudahan Aplikasi Perpajakan & 6 \\
\hline 5 & Peran DJPb & 6 \\
\hline 6 & Kepatuhan Pajak Bendahara Pemda & 5 \\
\hline \multicolumn{2}{|c|}{ Total } & 44 \\
\hline
\end{tabular}

(Sumber: data diolah)

Data sekunder yang digunakan dalam penelitian ini antara lain terkait data populasi dan data penyetoran pajak yang dilakukan oleh Bendahara Pemerintah. Data-data tersebut diperoleh penulis dari KPPN Penerimaan, Direktorat Jenderal perimbangan Keuangan (DJPK) dan DJP.

\subsection{Obyek, Lokasi dan Waktu Penelitian}

Obyek penelitian ini difokuskan pada Bendahara Pemda yang diduga memiliki tingkat kepatuhan pajak yang lebih rendah dibandingkan Bendahara Pemerintah Pusat. Lebih rendahnya tingkat kepatuhan Bendahara Pemda disebutkan oleh Subandi dan Fadhil (2018) berdasarkan pernyataan Direktur Potensi, Kepatuhan dan Penerimaan Ditjen Pajak yang menyebutkan bahwa meskipun dana Transfer Ke Daerah dan Dana Desa terus meningkat secara signifikan namun penerimaan pajak dari aktivitas di daerah masih rendah dan berada pada kisaran 3,6 persen.

Hal tersebut diperkuat dengan data dari DJP Dalam kurun waktu tahun 2013 s.d. 2017 kontribusi penerimaan pajak atas belanja APBD terhadap total penerimaan pajak nasional masih dalam kisaran 3 persen. Angka tersebut tentu saja masih belum optimal.

Tabel 5. Kontribusi Penerimaan Pajak Atas Belanja APBD Yang Disetor Bendahara Pemda Terhadap Total Penerimaan Pajak Tahun 2017

\begin{tabular}{|c|c|c|c|}
\hline Tahun & $\begin{array}{c}\text { Penerimaan } \\
\text { Pajak Atas } \\
\text { Belanja } \\
\text { APBD }\end{array}$ & $\begin{array}{c}\text { Penerimaan } \\
\text { Pajak } \\
\text { Nasional }\end{array}$ & $\%$ \\
\hline 2013 & 27,18 & 921 & 3,0 \\
\hline 2014 & 30,31 & 982 & 3,1 \\
\hline 2015 & 38,46 & 1.061 & 3,6 \\
\hline
\end{tabular}

\begin{tabular}{|l|l|l|l|}
2016 & 38,92 & 1.106 & 3,5 \\
\hline 2017 & 44,73 & 1.151 & 3,9 \\
\hline
\end{tabular}

(Sumber: Ditjen Pajak, 2018)

Lokasi penelitian difokuskan pada Bendahara Pemda dalam lingkup pulau Jawa yang meliputi enam propinsi besar yaitu Banten, Jawa Barat, DKI Jakarta, Jawa Tengah, DI Yogyakarta dan Jawa Timur. Pemilihan pulau Jawa sebagai lokasi penelitian didasarkan pada data kontribusi realisasi penerimaan pajak atas belanja APBD terbesar berada di pulau Jawa dengan kontribusi sebesar Rp19,8 triliun. Namun secara persentase dibandingkan dengan wilayah lain, persentase penerimaan pajak atas belanja APBD terhadap total penerimaan pajak lingkup pulau Jawa yang sebesar Rp444,6 triliun merupakan yang paling rendah dibandingkan wilayah regional lainnya yaitu hanya sebesar 4,4\%. Hal ini tentu saja perlu dilakukan penelitian agar dapat disusun rekomendasi kebijakan secara tepat.

Tabel 6. Kontribusi Penerimaan Pajak Atas Belanja APBD Yang Disetor Bendahara Pemda Terhadap Total Penerimaan Pajak Regional Tahun 2017 Berdasar Sebaran Wilayah

\begin{tabular}{|c|c|c|c|}
\hline $\begin{array}{c}\text { Wilayah } \\
\text { (Pulau) }\end{array}$ & $\begin{array}{c}\text { Penerimaan } \\
\text { Pajak Atas } \\
\text { Belanja } \\
\text { APBD }\end{array}$ & $\begin{array}{c}\text { Total } \\
\text { Penerimaan } \\
\text { Pajak } \\
\text { Regional }\end{array}$ & \% \\
\hline Sumatera & 10,3 & 75,4 & 13,7 \\
\hline Jawa & 19,8 & 444,6 & 4,4 \\
\hline $\begin{array}{c}\text { Bali Nusa } \\
\text { Tenggara }\end{array}$ & 2,8 & 13,3 & 20,7 \\
\hline Kalimantan & 4,2 & 33,6 & 12,4 \\
\hline Sulawesi & 4,9 & 19,4 & 25,3 \\
\hline $\begin{array}{c}\text { Maluku } \\
\text { Papua }\end{array}$ & 1,8 & 9,4 & 19,1 \\
\hline
\end{tabular}

(Sumber: Ditjen Pajak, 2018)

Jumlah populasi Bendahara Pemda lingkup Pulau Jawa (Provinsi Banten, DKI Jakarta, Jawa Barat, Jawa Tengah, DI Yogyakarta dan Jawa Timur) berdasarkan data NPWP yang diunduh dari database aplikasi Modul Penerimaan Negara (MPN) pada KPPN Penerimaan pada bulan Agustus 2019 berjumlah 7.482 bendahara. Berdasarkan rumus Slovin dengan menggunakan margin error 5 persen maka jumlah sampel penelitian yang dibutuhkan minimal berjumlah 380 responden.

Penyebaran kuisioner dilakukan pada tanggal 28 Oktober s.d. 6 November 2019. Pengambilan sampel dilakukan dengan menggunakan teknik stratified proportional 
random sampling. Teknik proportional stratified random sampling adalah teknik pengambilan sampel pada populasi yang berstrata dengan mengambil sampel dari tiap-tiap sub populasi yang jumlahnya disesuaikan dengan jumlah anggota dari masing-masing sub populasi secara acak atau serampangan. Dalam teknik stratified proportional random sampling, elemen populasi dikelompokkan pada tingkatan-tingkatan tertentu dengan tujuan pengambilan sampel merata pada seluruh tingkatan dan sampel mewakili karakter seluruh elemen populasi

\subsection{Metode Analisis Data}

a. Uji Validitas dan Reliabilitas Kuisioner Ghozali (2016) menyebutkan kuisioner harus dilakukan uji reliabilitas dan uji validitas terlebih dahulu sebelum disebarkan kepada responden.

(1) Uji Validitas

Uji Validitas dilakukan untuk mengukur valid tidaknya item pertanyaan atau pernyataan suatu kuesioner. Suatu kuesioner dikatakan valid jika pertanyaan pada kuesioner mampu untuk mengungkapkan sesuatu yang akan diukur oleh kuesioner tersebut. Ghozali (2016) menyebutkan untuk mengukur validitas kuisioner dengan cara melakukan korelasi bivariat antara masing-masing skor indikator dengan total skor variabel. Suatu butir pertanyaan/indikator pada kuesioner dinyatakan valid apabila pada bagian Total Korelasi Pearson masing-masing indikator mempunyai koefisien korelasi lebih besar dari nilai $r$ tabel.

(2) Uji Reliabilitas

Uji Reliabilitas dilakukan untuk mengukur konsistensi jawaban dari responden. Suatu kuisioner reliabel atau handal jika jawaban responden terhadap pernyataan adalah konsisten dari waktu ke waktu. Ghozali (2016) menyebutkan pengukuran reliabilitas dapat dilakukan dengan cara One Shot Measures dimana pengukuran hanya dilakukan sekali dan kemudian hasilnya dibandingkan dengan pertanyaan lain atau mengukur korelasi antar jawaban pertanyaan. Hasil dari uji ini akan terlihat pada nilai uji statistik Cronbach Alpha ( $\alpha)$. Hair et al (2010) menyebutkan bahwa suatu variabel dikatakan memiliki reliabilitas yang moderat/cukup jika memberikan nilai Croncbach Alpha > nilai 0,5. b. Regresi Logistik

Data primer yang dihasilkan dari kuisioner dianalisis dengan menggunakan Analisis Multivariat. Menurut Suliyanto (2005), Analisis Multivariat merupakan suatu metode statistika yang tujuan penggunaannya adalah untuk menganalisis data yang terdiri dari banyak variabel serta diduga antar variabel tersebut saling berhubungan satu sama lain.

Jenis Analisis Multivariat yang digunakan dalam penelitian ini adalah regresi logistik. Penggunaan regresi logistik dalam penelitian menurut Ghozali (2016) dikarenakan adanya asumsi multivariate normal distribution yang tidak dapat dipenuhi karena variabel bebas merupakan campuran antara variabel kontinyu (metrik) dan kategorial (non-metrik). Dalam regresi logistik, variabel terikat adalah data nominal/kategorial khususnya data binary (Santoso, 2016).

Kategori paling dasar dari model logit menghasilkan binary value misalnya angka 0 dan 1. Angka yang dihasilkan mewakili suatu kategori tertentu yang diperoleh dari perhitungan probabilitas terjadinya kategori tersebut. Bentuk dasar probabilitas dalam model logit dapat dijelaskan pada tabel berikut:

Tabel 7. Probabilitas Model Logit

\begin{tabular}{|c|c|}
\hline $\mathbf{Y}_{\mathbf{1}}$ & Probabilitas \\
\hline 0 & $1-\mathrm{Pi}$ \\
\hline 1 & $\mathrm{P}_{\mathrm{i}}$ \\
\hline Total & $\mathbf{1}$ \\
\hline
\end{tabular}

(Sumber: Gujarati, 2003)

Penggunaan model logit digunakan dalam penelitian Sigit (2019) untuk mengevaluasi kondisi RPD Harian akurat dan RPD Harian tidak akurat. Dalam kategori capaian Rencana Penarikan Dana (RPD) Harian dimana nilai 0 memiliki arti RPD Harian tidak akurat dan nilai 1 memiliki arti RPD Harian akurat. Penentuan terjadinya RPD Harian Akurat atau tidak akurat dipengaruhi oleh variabel bebas (Sigit, 2019).

Persamaan regeresi model logit diperoleh dari penurunan persamaan probabilitas dari kategori-kategori yang akan diestimasi. Persamaan Regresi Logit adalah sebagai berikut :

$$
\begin{aligned}
& \mathrm{Li}=\ln \left\{\frac{P_{i}}{1-P_{i}}\right\}=\mathrm{Zi}=\beta 1+\beta 2 \mathrm{Xi} \\
& \text { Persamaan } \frac{P_{i}}{1-P_{i}} \quad \text { disebut dengan rasio }
\end{aligned}
$$
kecenderungan (odds ratio) terjadinya kategori dengan nilai 1 atau dalam penelitian ini adalah terjadinya kondisi Bendahara Pemerintah Patuh dalam menyetorkan pajak. Apabila $\mathrm{Pi}=$ 
0.8 maka kecenderungan terjadinya kondisi Bendahara Pemerintah Patuh semakin besar.

c. Evaluasi Model Dalam Regresi Logit

Santoso (2016) menyebutkan evaluasi model yang akan dilakukan dalam regresi logistik antara lain:

\section{(1) Omnibus Tests of Model Coefficients}

Nilai signifikansi Omnibus Tests dengan jumlah variabel bebas sebanyak $\mathrm{x}$ harus berada di bawah 0,05 (taraf signifikansi 5 persen). Hal tersebut menunjukkan bahwa terdapat pengaruh yang signifikan dari $\mathrm{x}$ variabel bebas secara simultan memengaruhi variabel terikat. Hipotesis yang dikembangkan adalah :

H0 : penambahan variabel bebas tidak dapat memberikan pengaruh nyata terhadap model.

H1 : penambahan variabel bebas dapat memberikan pengaruh nyata terhadap model.

\section{(2) Nagelkerke's R Square}

Nagelkerke's $R$ Square juga dikenal dengan Koefisien Determinasi (R2) yang digunakan untuk mengetahui seberapa besar variabilitas variabel bebas mampu menjelaskan variabel terikat.

(3) Hosmer and Lemeshow's Goodness of Fit Test

Hosmer and Lemeshow's Goodness of Fit Test menguji hipotesis nol bahwa data empiris cocok atau sesuai dengan model (tidak ada perbedaan antara model dengan data sehingga model dapat dikatakan fit). Hipotesis yang dikembangkan adalah :

H0 : Tidak ada perbedaan nyata antara klasifikasi yang diprediksi dan klasifikasi yang diamati atau model fit dengan data.

H1 : Ada perbedaan yang nyata antara klasifikasi yang diprediksi dan klasifikasi yang diamati atau model tidak fit dengan data.

\section{(4) Uji Simultan dan Uji Parsial}

Untuk mengetahui pengaruh variabel bebas terhadap variabel terikat secara bersama-sama di dalam model dapat menggunakan uji G atau Likelihood Ratio Test. Statistik uji yang digunakan adalah :

$$
\mathrm{G}^{2}=-2 \ln \left|\frac{L_{0}}{L_{1}}\right|
$$

Statistik G mengikuti distribusi chisquare dengan derajat bebas $\mathrm{p}$ sehingga hipotesis ditolak jika nilai probabilitas $\geq$ chisquare atau $p$-value $\leq \alpha$ yang berarti variabel bebas $X$ secara bersama-sama memengaruhi variabel terikat Y. Hipotesisnya dapat dituliskan sebagai berikut:

H0 : $\beta 1=\beta 2=\ldots .=\beta p=0$ (tidak ada pengaruh variabel bebas secara simultan terhadap variabel terikat)

H1 : Minimal ada satu $\beta i \neq 0 ; i=1,2, \ldots, p$ (ada pengaruh variabel bebas secara simultan terhadap variabel terikat)

Uji parsial digunakan untuk mencari model yang cocok dan keterkaitan kuat antara model dengan datanya atau untuk mengetahui pengaruh koefisien $\beta$ dibandingkan dengan standar erornya. Uji parsial akan menggunakan uji wald. Statistik uji yang digunakan adalah:

$$
\mathrm{W}=\left(\frac{\beta_{i}}{S E\left(\beta_{i}\right)}\right)^{2}
$$

Hipotesis yang digunakan adalah :

$\mathrm{HO}: \beta \mathrm{i}=0$ (tidak ada pengaruh variabel bebas terhadap variabel terikat)

$\mathrm{H} 1: \beta \mathrm{i} \neq 0$ (ada pengaruh variabel bebas terhadap variabel terikat)

Hipotesis nol akan ditolak jika p-value $\leq \alpha$ yang berarti secara parsial variabel bebas $\mathrm{X}$ memengaruhi variabel terikat Y.

\section{(5) Odds Ratio}

Odds ratio (rasio peluang) merupakan ukuran risiko atau kecenderungan untuk mengalami kejadian sukses antara satu kategori dengan kategori lainnya. Regresi logistik binary akan menghasilkan odds ratio terkait dengan nilai setiap prediktor. Rasio peluang bagi prediktor diartikan sebagai jumlah relatif dimana peluang hasil meningkat (dimana rasio peluang $>1$ ) atau turun (dimana rasio peluang $<1$ ) ketika variabel bebas mengalami peningkatan sebesar 1 unit.

\subsection{Model Penelitian}

Variabel bebas yang digunakan dalam penelitian ini adalah Pengetahuan Perpajakan, Sikap Terhadap Kewajiban Perpajakan, Kualitas Pelayanan Perpajakan, Kemudahan Aplikasi Perpajakan dan Peran DJPb sedangkan sebagai variabel terikat adalah Kepatuhan Pajak Bendahara Pemda. Variabel Kepatuhan Pajak Bendahara Pemda nantinya merupakan data kategorial dengan kriteria 1 = Bendahara Patuh 
dan $0=$ Bendahara Tidak Patuh. Dengan demikian model persamaan penelitian adalah sebagai berikut :

$\operatorname{Ln}\left\{\frac{P_{i}}{1-P_{i}}\right\}=\alpha+\beta 1 \mathrm{PPi}+\beta 2 \mathrm{SKPi}+\beta 3 \mathrm{KPPi}+\beta 4$ KAPi $+\beta 5$ PDi

dengan penjelasan :

$\operatorname{Ln} \frac{\mathrm{P}}{1-\mathrm{P}}$ : $\quad$ Mengacu pada probabilitas untuk Bendahara Pemda patuh dibandingkan dengan Bendahara Pemda tidak patuh

PP : Pengetahuan Perpajakan

SKP : Sikap Terhadap Kewajiban Perpajakan

KPP : Kualitas Pelayanan Perpajakan

KAP : Kemudahan Aplikasi Perpajakan

PD : Peran DJPb

i $\quad$ : $\quad(1,2 \ldots \ldots \ldots . . .877)$

\section{HASIL PENELITIAN}

\subsection{Hasil Uji Validitas dan Reliabilitas}

Penyebaran kuisioner untuk uji validitas dan reliabilitas dilaksanakan pada hari Senin tanggal 21 Oktober 2019 kepada responden Bendahara Pengeluaran lingkup Pemerintah Kota Bogor bertempat di KPPN Bogor dengan jumlah total 37 responden.

Setelah dilakukan tabulasi data dan dilakukan uji validitas dan uji reabilitas dengan menggunakan alat pengolah data, seluruh indikator variabel pada kuisioner dinyatakan valid dengan Nilai Corrected Item-Total Correlation seluruhnya lebih besar dari nilai tabel $r$ yang sebesar 0,36 dan seluruh variabel dinyatakan reliabel dengan capaian nilai Croncbach's Alpha lebih besar dari 0,6.

\subsection{Deskripsi Data Penelitian}

a. Responden Penelitian

Setelah seluruh kuisioner dinyatakan valid dan reliabel, dilakukan penyebaran kuisioner kepada Bendahara Pemda lingkup Pulau Jawa. Total data responden yang berhasil dilakukan tabulasi berjumlah 877 responden dengan rincian sebagai berikut :

Tabel 8. Sebaran Responden Per Propinsi

\begin{tabular}{|c|l|c|}
\hline No & \multicolumn{1}{|c|}{ Propinsi } & Jumlah Responden \\
\hline 1 & Banten & 24 \\
\hline 2 & DI Yogyakarta & 42 \\
\hline 3 & DKI Jakarta & 82 \\
\hline 4 & Jawa Barat & 245 \\
\hline
\end{tabular}

\begin{tabular}{|l|l|l|}
5 & Jawa Tengah & 213 \\
\hline 6 & Jawa Timur & 271 \\
\hline \multicolumn{2}{|c|}{ Total } & $\mathbf{8 7 7}$ \\
\hline
\end{tabular}

(Sumber: data diolah)

b. Hasil Deskriptif Kuisioner Variabel Kepatuhan Pajak Bendahara Pemda

Berdasarkan hasil pengolahan data kuisioner diketahui bahwa dari 877 responden sebanyak 489 responden $(55,76 \%)$ tidak memiliki kepatuhan dalam pelaksanaan kewajiban perpajakan Bendahara Pemda dengan capaian nilai < dari nilai rata-rata total yang menjadi treshold yang sebesar 20,46 sedangkan sebanyak 388 responden $(44,24 \%)$ memiliki kepatuhan dalam pelaksanaan kewajiban perpajakan Bendahara Pemda dengan capaian nilai $\geq$ dari nilai rata-rata total 20,46 .

Tabel 9: Hasil Kuisioner Indikator Kepatuhan Bendahara Dalam Logit

\begin{tabular}{|c|c|c|}
\hline Kriteria & Jumlah & \% \\
\hline Tidak Patuh & 489 & $55,76 \%$ \\
\hline Patuh & 388 & $44,24 \%$ \\
\hline Jumlah & $\mathbf{8 7 7}$ & $100,00 \%$ \\
\hline
\end{tabular}

(Sumber: data diolah)

Hasil tersebut sesuai dengan indikasi awal dimana antara lain Subandi dan Fadhil (2018) yang menyebutkan bahwa Kepatuhan Pajak Bendahara Pemda dalam lingkup Pulau Jawa masih cukup rendah.

\subsection{Analisis Hasil Regresi Logistik}

a. Omnibus Test of Model Coefficients

Hasil dari nilai chi-square hitung sebesar 891.840 > nilai chi-square tabel pada Degree of Freedom (DF) sejumlah variabel bebas yang berjumlah 5 yaitu 11.071. Jika mengacu pada nilai signifikansinya, maka nilai $0.000<0.05(\alpha$ $=5 \%$ ) sehingga $\mathrm{H} 0$ ditolak.

Hasil tersebut menunjukkan bahwa penambahan variabel independen dapat memberikan pengaruh nyata terhadap model atau dengan kata lain model dinyatakan Fit.

\section{b. Nagelkerke R Square}

Nilai Nagelkerke $R$ Square yang dihasilkan adalah sebesar 0,855 . Hal tersebut menunjukkan bahwa kemampuan variabel bebas dalam menjelaskan variabel terikat adalah sebesar 85,5 persen dan terdapat 14,5 persen faktor-faktor lainnya di luar model yang menjelaskan variabel terikat. 


\section{c. Hosmer and Lemeshow Test}

Nilai chi-square tabel untuk DF 8 pada $\alpha=$ 0.05 adalah sebesar 15.507. Karena nilai chisquare Hosmer and Lemeshow hitung sebesar 10.995, maka nilai chi-square Hosmer and Lemeshow hitung < nilai chi-square tabel. Jika mengacu pada nilai signifikansinya maka menghasilkan nilai $0.202>0.05$ sehingga $\mathrm{H} 0$ gagal untuk ditolak.

Hasil tersebut menunjukkan bahwa model dapat diterima dan pengujian hipotesis dapat dilakukan dikarenakan tidak ada perbedaan signifikan antara model dengan nilai observasinya.

\section{d. Tabel Klasifikasi}

Nilai overall percentage penelitian ini sebesar 0.922 yang berarti ketepatan model yang digunakan dalam penelitian ini adalah sebesar 92.2 persen.

\section{e. Hasil Uji Simultan}

Untuk menguji secara simultan pada regresi logistik menggunakan pengujian maximum likelihood. Uji simultan ditunjukkan dengan nilai $\mathrm{G}^{2}$ dimana nilainya $=-2 \ln (\mathrm{L} 0)-[-2 \ln (\mathrm{L} 1)]=$ $1204.123-312.283=891.84$. Untuk melihat signifikansinya, hasil dari nilai $\mathrm{G}^{2}$ dibandingkan dengan nilai chi-square tabel dengan derajat bebas sebesar banyaknya variabel bebas (DF $=5$ ) yaitu sebesar 11.070. Karena nilai $G^{2}$ yaitu sebesar 891.84 > nilai chi-square yaitu sebesar 11.070 maka H0 ditolak.

Hasil tersebut berarti bahwa variabel Pengetahuan Perpajakan, Sikap Terhadap Kewajiban Perpajakan, Kualitas Pelayanan Perpajakan, Kemudahan Aplikasi Perpajakan dan Peran DJPb secara bersama-sama berpengaruh terhadap Kepatuhan Pajak Bendahara Pemda.

\section{f. Hasil Uji Parsial}

Uji Parsial dilakukan dengan menggunakan hasil uji wald. Hasil dari uji wald ditunjukkan dalam tabel berikut ini:

Tabel 10. Hasil Uji Wald

\begin{tabular}{|l|r|r|r|r|r|r|}
\hline \multicolumn{7}{|c|}{ Variables in the Equation } \\
\hline Var & \multicolumn{1}{c|}{ B } & \multicolumn{1}{c|}{ S.E. } & \multicolumn{1}{c|}{ Wald } & df & \multicolumn{1}{c|}{ Sig. } & Exp(B) \\
\hline PP &, 774 &, 112 & 47,834 & 1 &, 000 & 2,168 \\
\hline SKP &, 169 &, 057 & 8,825 & 1 &, 003 & 1,184 \\
\hline KPP & 1,004 &, 118 & 72,874 & 1 &, 000 & 2,728 \\
\hline KAP &, 222 &, 083 & 7,212 & 1 &, 007 & 1,249 \\
\hline PD &, 024 &, 059 &, 170 & 1 &, 681 & 1,024 \\
\hline Cons & - & 5,737 & 139,734 & 1 &, 000 &, 000 \\
\hline
\end{tabular}

\section{(Sumber: data diolah)}

Berdasarkan nilai-nilai pada koefisien B pada tabel di atas, maka model persamaan yang dapat dibentuk adalah sebagai berikut:

$$
\begin{gathered}
\operatorname{Ln}\left\{\frac{P_{i}}{1-P_{i}}\right\}=-67,817+0,774 \mathrm{PP}^{*}+0,169 \mathrm{SKP}^{*}+ \\
1,004 \mathrm{KPP}^{*}+0,222 \mathrm{KAP}^{*}+0,024 \\
\text { PD }
\end{gathered}
$$

Dari tabel hasil Uji Wald di atas menunjukkan bahwa terdapat empat variabel bebas yang memiliki nilai $P$-value uji wald dengan nilai Sig $<\alpha 5 \%$, yang berarti empat variabel bebas tersebut secara parsial memiliki pengaruh terhadap variabel terikat di dalam model.

Keempat variabel bebas yang memiliki pengaruh secara parsial terhadap Kepatuhan Pajak Bendahara Pemda tersebut adalah Pengetahuan Perpajakan (PP), Sikap Terhadap Kewajiban Perpajakan (SKP), Kualitas Pelayanan Perpajakan (KPP) dan Kemudahan Aplikasi Perpajakan (KAP). Sedangkan variabel Peran $\mathrm{DJPb}$ (PD) tidak memiliki pengaruh secara statistik terhadap Kepatuhan Pajak Bendahara Pemda.

Besarnya pengaruh variabel bebas ditunjukkan dengan nilai EXP (B) atau odds ratio dengan rincian sebagai berikut :

(1) Pengaruh Pengetahuan Perpajakan Terhadap Kepatuhan Pajak Bendahara Pemda

Pengetahuan Perpajakan mempunyai nilai sig wald 0,000 $<0,05(\alpha=5 \%)$ sehingga H0 ditolak atau berarti Pengetahuan Perpajakan mempunyai pengaruh terhadap terjadinya kondisi Bendahara Pemerintah yang patuh. Pengetahuan Perpajakan memiliki nilai odds ratio sebesar 2,168 yang berarti jika Pengetahuan Perpajakan yang dimiliki tinggi maka memiliki kecenderungan terjadinya Bendahara Pemerintah yang patuh sebesar 2,168 kali lipat dibandingkan ketika Pengetahuan Perpajakan yang dimiliki rendah. Nilai B sebesar 0,774 merupakan Logaritma Natural dari Exp (B) sebesar 2,168. Karena nilai B bernilai positif maka variabel Pengetahuan Perpajakan mempunyai hubungan positif dengan Kepatuhan Pajak Bendahara Pemda.

Hasil penelitian ini sama dengan penelitian sebelumnya antara lain Hardiningsih dan Yulianawati (2011), Afni (2013), Suyapto dan Lasmana (2014) serta Asfa dan Meiranto (2017) yang menyimpulkan Pengetahuan Perpajakan berpengaruh terhadap Kepatuhan Wajib Pajak. 
(2) Pengaruh Sikap Terhadap Kewajiban Perpajakan Terhadap Kepatuhan Pajak Bendahara Pemda

Sikap Terhadap Kewajiban Perpajakan mempunyai nilai sig wald 0,003 $<0,05$ $(\alpha=5 \%)$ sehingga $\mathrm{H} 0$ ditolak atau berarti Sikap Terhadap Kewajiban Perpajakan mempunyai pengaruh terhadap terjadinya kondisi Bendahara Pemerintah yang patuh. Sikap Terhadap Kewajiban Perpajakan memiliki nilai odds ratio sebesar 1,184 yang berarti jika Sikap terhadap Kewajiban Perpajakan yang dimiliki tinggi maka memiliki kecenderungan terjadinya Bendahara Pemerintah yang patuh sebesar 1,184 kali lipat dibandingkan ketika Sikap Terhadap Kewajiban Perpajakan yang dimiliki rendah. Nilai B sebesar 0,169 merupakan Logaritma Natural dari Exp (B) sebesar 1,184. Karena nilai B bernilai positif maka variabel Sikap Terhadap Kewajiban Perpajakan mempunyai hubungan positif dengan Kepatuhan Bendahara Pemerintah.

Hasil penelitian ini sama dengan penelitian sebelumnya antara lain Hardiningsih dan Yulianawati (2011), Suyapto dan Lasmana (2014), Dharma dan Ariyanto (2014), Asfa dan Meiranto (2017), Subandi dan Fadhil (2018) serta Listyowati, Samrotun dan Suhendro (2018) yang menyimpulkan bahwa Sikap Kesadaran Dalam Membayar pajak berpengaruh terhadap Kepatuhan Wajib Pajak.

(3) Pengaruh Kualitas Pelayanan Perpajakan Terhadap Kepatuhan Pajak Bendahara Pemda

Kualitas Pelayanan Perpajakan mempunyai nilai sig wald 0,000 < 0,05 $(\alpha=5 \%$ ) sehingga H0 ditolak atau berarti Kualitas Pelayanan Perpajakan mempunyai pengaruh terhadap terjadinya kondisi Bendahara Pemerintah yang patuh. Kualitas Pelayanan Perpajakan memiliki nilai odds ratio sebesar 2,728 yang berarti jika Kualitas Pelayanan Perpajakan yang dimiliki tinggi maka memiliki kecenderungan terjadinya Bendahara Pemerintah yang patuh sebesar 2,728 kali lipat dibandingkan ketika Kualitas Pelayanan Perpajakan yang dimiliki rendah. Nilai B sebesar 1,004 merupakan Logaritma Natural dari Exp (B) sebesar 2,728. Karena nilai B bernilai positif maka variabel Kualitas Pelayanan Perpajakan mempunyai hubungan positif dengan Kepatuhan Bendahara Pemerintah.
Hasil penelitian ini sama dengan penelitian sebelumnya antara lain Hardiningsih dan Yulianawati (2011), Fuadi dan Mangoting (2013), Suyapto dan Lasmana (2014) serta Susherdianto (2014) yang menyimpulkan bahwa fungsi pelayanan yang berjalan dengan baik meningkatkan Kepatuhan Wajib Pajak.

(4) Pengaruh Kemudahan Aplikasi Perpajakan Terhadap Kepatuhan Pajak Bendahara Pemda

Kemudahan Aplikasi Perpajakan mempunyai nilai sig wald $0,007<0,05$ $(\alpha=5 \%)$ sehingga $\mathrm{HO}$ ditolak atau berarti Kemudahan Aplikasi Perpajakan mempunyai pengaruh terhadap terjadinya kondisi Bendahara Pemerintah yang patuh. Kemudahan Aplikasi Perpajakan memiliki nilai odds ratio sebesar 1,249 yang berarti jika Kemudahan Aplikasi Perpajakan yang dimiliki tinggi maka memiliki kecenderungan terjadinya Bendahara Pemerintah yang patuh sebesar 1,249 kali lipat dibandingkan ketika Kemudahan Aplikasi Perpajakan yang dimiliki rendah. Nilai B sebesar 0,222 merupakan Logaritma Natural dari Exp (B) sebesar 1,249. Karena nilai B bernilai positif maka variabel Kemudahan Aplikasi Perpajakan mempunyai hubungan positif dengan Kepatuhan Bendahara Pemerintah.

Hasil penelitian ini sama dengan penelitian sebelumnya antara lain Lee (2016) yang menyimpulkan bahwa pengenaan sistem pemungutan pajak secara elekronik meningkatkan Kepatuhan Wajib Pajak di Korea Selatan.

(5) Pengaruh Peran DJPb Terhadap Kepatuhan Pajak Bendahara Pemda

Peran $\mathrm{DJPb}$ mempunyai nilai sig wald $0,6818>0,05(\alpha=5 \%)$ sehingga $\mathrm{HO}$ gagal untuk ditolak atau berarti tidak ada pengaruh secara statistik variabel Peran $\mathrm{DJPb}$ terhadap kondisi Bendahara Pemerintah yang patuh. Tidak berpengaruhnya secara statistik variabel Peran DJPb dapat disebabkan varian jawaban responden yang cenderung sama besar antara responden yang memilih Ya dan responden yang memilih Netral\&Tidak dalam setiap pertanyaan indikator sehingga hal tersebut dapat memengaruhi pengaruh variabel Peran DJPb secara keseluruhan.

Hal tersebut terlihat dari hasil olah data per indikator kuisoner dalam tabel di bawah ini : 


\begin{tabular}{|c|c|c|c|c|}
\hline \multicolumn{5}{|c|}{$\begin{array}{l}\text { Tabel 11. Hasil Kuisioner Indikator } \\
\text { Peran DJPb }\end{array}$} \\
\hline Peran DJPb & Ya & Tidak & Netral & Jumlah \\
\hline $\begin{array}{l}\text { Asistensi } \\
\text { Pembuatan Kode } \\
\text { Billing }\end{array}$ & 389 & 89 & 399 & 877 \\
\hline $\begin{array}{l}\text { Asistensi } \\
\text { Perhitungan } \\
\text { Pajak }\end{array}$ & 344 & 100 & 433 & 877 \\
\hline $\begin{array}{l}\text { Sosialisasi } \\
\text { Kewajiban } \\
\text { Perpajakan }\end{array}$ & 438 & 67 & 372 & 877 \\
\hline $\begin{array}{l}\text { Pelatihan } \\
\text { Aplikasi }\end{array}$ & 398 & 74 & 405 & 877 \\
\hline $\begin{array}{l}\text { Mengetahui } \\
\text { Fasilitas HaiDJPb }\end{array}$ & 311 & 294 & 272 & 877 \\
\hline $\begin{array}{l}\text { Memanfaatkan } \\
\text { Fasilitas HaiDJPb }\end{array}$ & 259 & 259 & 359 & 877 \\
\hline
\end{tabular}

\section{(Sumber: data diolah)}

Berdasarkan Tabel 11, Peran DJPb relatif cukup besar dengan penilaian responden rata-rata mencapai 40 persen untuk setiap indikator. Misalnya terkait adanya peran KPPN dalam pembuatan kode billing, sebanyak 389 responden $(44,35 \%)$ menyebutkan mereka pernah mendapatkan asistensi dari KPPN dalam pembuatan kode billing sebelum melakukan penyetoran pajak. Begitu juga terkait sosialisasi KPPN dalam kewajiban perpajakan Bendahara Pemda, sebanyak 438 responden $(49,94 \%)$ menyebutkan mereka pernah mendapatkan sosialisasi kewajiban perpajakan dari KPPN. Begitu juga terkait pelatihan aplikasi penyetoran dan pelaporan pajak, sebanyak 398 responden (45,38\%) menyebutkan bahwa mereka pernah mendapatkan pelatihan aplikasi penyetoran dan pelaporan pajak.

Capaian KPPN dalam data-data tersebut menunjukkan DJPb c.q. KPPN sudah berperan dalam pelaksanaan kewajiban perpajakan Bendahara Pemda meskipun belum maksimal.

Terdapat beberapa hal yang menyebabkan Peran DJPb masih belum maksimal dalam hal pelaksanaan kewajiban Bendahara Pemda ini, antara lain:

(a) DJPb c.q. KPPN belum memiliki akses kewenangan yang cukup dalam melakukan pembinaan Bendahara Pemda dikarenakan hubungan antara KPPN dengan Pemda baru sebatas pencairan Dana Desa dan DAK Fisik sebagaimana diatur dalam PMK Nomor 50/PMK.07/2017 dimana Kepala KPPN berperan sebagai Kuasa Pengguna Anggaran (KPA) Penyalur
Dana Desa dan DAK Fisik. Dengan terbatasnya jenis pencairan belanja yang dilakukan Pemda di KPPN tersebut, hubungan yang dibangun KPPN kepada Pemda masih relatif terbatas.

(b) Belum adanya sinergi yang cukup antara DJP c.q. KPP dengan DJPb c.q. KPPN dalam hal pembagian tugas pembinaan kepatuhan perpajakan Bendahara Pemerintah. Menteri Keuangan dalam berbagai kesempatan Rapat Pimpinan Kementerian Keuangan yang diikuti oleh penulis mengharapkan intensifikasi dan pembinaan perpajakan kepada Bendahara Pemerintah dilakukan DJPb sebagai pembina Bendahara Pemerintah sedangkan DJP fokus pada intensifikasi dan ekstensifikasi perpajakan di luar Bendahara Pemerintah (sektor swasta).

(c) Tidak adanya koordinator yang menjadi leader dalam koordinasi kebijakan fiskal di daerah. Hal tersebut menyebabkan akselerasi penyelesaian berbagai permasalahan di daerah baik terkait penerimaan ataupun pengeluaran relatif tidak maksimal.

Menyikapi berbagai permasalahan tersebut, penulis mengusulkan rekomendasi sebagai berikut:

(1) Dalam jangka pendek, untuk mengamankan penerimaan pajak agar dapat masuk ke kas negara secara tepat waktu dan tepat jumlah dengan kondisi Kepatuhan Pajak Bendahara Pemda yang masih cukup rendah, dapat diterapkan Kebijakan Penyetoran Pajak Terintegrasi Pencairan Dana Belanja Daerah (SP2D Online). Dengan penerapan SP2D Online, Penyetoran Pajak dilakukan bersamaan penyaluran dana ke pihak ketiga pada mekanisme Pembayaran secara langsung (LS). Saat ini penerapan SP2D Online baru dilakukan uji coba secara terbatas pada bank persepsi di Propinsi DKI Jakarta yaitu Bank DKI dan Propinsi Sumatera Utara yaitu Bank Sumut. Dengan memperhatikan kondisi kepatuhaan pajak Bendahara Pemda dalam menyetorkan pajak yang masih cukup rendah, kebijakan penerapan SP2D Online dapat diperluas di Propinsi lainnya.

(2) Perlu dilakukan kajian kembali terkait kewenangan KPPN dalam melakukan penyaluran seluruh jenis Dana Transfer Ke Daerah dengan tidak hanya terbatas pada 
penyaluran Dana Desa dan DAK Fisik. Dengan melakukan penyaluran seluruh Dana Transfer Ke Daerah maka KPPN akan memiliki kewenangan yang besar dalam melakukan pembinaan dan pengawasan terhadap Bendahara Pemda termasuk di dalamnya melakukan pengawasan terkait kepatuhan kewajiban perpajakan Bendahara Pemda. Agar hal tersebut dapat dilaksanakan, maka perlu adanya pengaturan pemberian kewenangan kepada $\mathrm{DJPb}$ melalui PMK. Berdasarkan kewenangan yang diatur dalam PMK tersebut, DJPb c.q. Kanwil DJPb dan KPPN akan dapat melaksanakan review dan evaluasi penyaluran Dana Transfer Ke Daerah dan Dana Desa yang disalurkan di wilayah kerjanya. Hal tersebut diharapkan akan dapat meningkatkan efisiensi dan efektivitas pelaksanaan APBN di daerah.

(3) Perlunya peningkatan sinergi antara KPPN dengan KPP melalui adanya kesepakatan bersama pada level pimpinan DJPb dan DJP sehingga dalam implementasi di lapangan KPPN mendapatkan dukungan yang cukup dalam melakukan kegiatan pembinaan kewajiban perpajakan Bendahara Pemda.

(4) Perlu adanya penugasan kepada salah satu Kanwil dari Eselon I Kementerian Keuangan untuk setiap propinsi yang berfungsi sebagai koordinator dalam kegiatan koordinasi kebijakan fiskal di daerah. Salah satu pilihan yang dapat diambil adalah dengan menunjuk Kanwil DJPb sebagai koordinator tersebut karena selama ini Kanwil DJPb sudah berperan sebagai pelaksana fungsi treasury di daerah. Peran sebagai fungsi treasury tersebut penting dilakukan oleh Kanwil DJPb di daerah untuk memastikan pelaksanaan cash management dapat terlaksana dengan baik. Kanwil DJPb selama ini juga sudah rutin mendapatkan berbagai pelimpahan tugas dari unit Eselon I lainnya seperti DJPK, DJPPR dan BKF dalam pelaksanaan tugas tertentu. Hal-hal tersebut menurut penulis menjadikan Kanwil DJPb layak untuk menjadi koordinator kebijakan fiskal di daerah.

\section{KESIMPULAN}

\subsection{Kesimpulan}

Berdasarkan hasil analisis dapat disimpulkan sebagai berikut:

1. Pengetahuan Perpajakan, Sikap Terhadap Kewajiban Perpajakan, Kualitas Pelayanan
Perpajakan, Kemudahan Aplikasi Perpajakan dan Peran DJPb secara bersama-sama memiliki pengaruh terhadap Kepatuhan Pajak Bendahara Pemda.

2. Secara parsial, pengaruh dari tiap-tiap variabel adalah sebagai berikut:

a. Pengetahuan Perpajakan, Sikap Terhadap Kewajiban Perpajakan, Kualitas Pelayanan Perpajakan, Kemudahan Aplikasi Perpajakan mampu memberikan pengaruh positif terhadap Kepatuhan Pajak Bendahara Pemda.

b. Variabel Peran DJPb tidak memiliki pengaruh secara statistik terhadap Kepatuhan Pajak Bendahara Pemda.

3. Berdasarkan hasil pengolahan data kuisioner diketahui bahwa dari 877 responden sebanyak 489 responden $(55,76 \%)$ tidak memiliki kepatuhan dalam pelaksanaan kewajiban perpajakan Bendahara Pemda dengan capaian nilai < dari nilai rata-rata total yang menjadi treshold yang sebesar 20,46 sedangkan sebanyak 388 responden $(44,24 \%)$ memiliki kepatuhan dalam pelaksanaan kewajiban perpajakan Bendahara Pemda dengan capaian nilai $\geq$ dari nilai rata-rata total 20,46 .

\subsection{Saran}

Berkaitan dengan hasil pengujian dan kesimpulan tersebut, diberikan rekomendasi sebagai berikut:

1. Untuk mengatasi permasalahan Kepatuhan Pajak Bendahara Pemda yang masih cukup rendah, dalam jangka pendek dapat diterapkan Kebijakan Penyetoran Pajak Terintegrasi Pencairan Dana Belanja Daerah (SP2D Online) dimana penyetoran pajak dilakukan bersamaan penyaluran dana ke pihak ketiga pada mekanisme Pembayaran secara langsung (LS).

2. Dengan berpengaruhnya Pengetahuan Perpajakan, Sikap Terhadap Kewajiban Perpajakan, Kualitas Pelayanan Perpajakan dan Kemudahan Aplikasi Perpajakan terhadap Kepatuhan Pajak Bendahara Pemda, DJP perlu terus meningkatkan sosialisasi dan penyuluhan terkait pemahaman dan kesadaran pajak kepada wajib apajak. DJP juga perlu terus menjaga dan meningkatkan kualitas pelayanan kepada wajib pajak terutama di KPP. DJP juga perlu terus bekerjasama dengan stakeholder terkait seperti DJPb untuk melakukan penyempurnaan aplikasi penyetoran dan pelaporan pajak sehingga semakin 
memberikan kemudahan kepada wajib pajak dalam melakukan pembayaran pajak.

3. Perlu dilakukan kajian terkait perluasan kewenangan KPPN dalam melakukan penyaluran seluruh jenis Dana Transfer Ke Daerah dan Dana Desa dengan tidak hanya terbatas pada penyaluran Dana Desa dan DAK Fisik sehingga KPPN akan memiliki kewenangan yang lebih besar dalam melakukan pembinaan kepada Bendahara Pemda termasuk dalam pelaksanaan kewajiban perpajakannya.

4. Perlunya peningkatan sinergi antara KPPN dengan KPP melalui adanya kesepakatan bersama pada level pimpinan DJPb dan DJP sehingga KPPN akan mendapatkan dukungan yang cukup dalam melakukan kegiatan pembinaan kewajiban perpajakan Bendahara Pemda.

5. Perlu adanya penugasan kepada salah satu Kanwil dari Eselon I Kementerian Keuangan untuk setiap propinsi yang berfungsi sebagai koordinator dalam kegiatan koordinasi kebijakan fiskal di daerah dengan opsi yang dapat dipilih adalah Kanwil DJPb selaku pelaksana fungsi treasury di daerah dan Kanwil DJPb sudah rutin mendapatkan berbagai pelimpahan tugas dari unit Eselon I lainnya seperti DJPK, DJPPR dan BKF dalam pelaksanaan tugas tertentu.

\section{IMPLIKASI DAN KETERBATASAN}

\subsection{Implikasi Penelitian}

Implikasi penelitian ini dari aspek praktis diharapkan dapat memberikan manfaat bagi Kementerian Keuangan c.q. Direktorat Jenderal Pajak, Direktorat Jenderal Perimbangan Keuangan dan Direktorat Jenderal Perbendaharaan serta Pemerintah Daerah dalam ranah implementasi dan evaluasi kebijakan terkait kepatuhan penyetoran pajak Bendahara Pemerintah Daerah.

\subsection{Keterbatasan Penelitian}

Penelitian ini terbatas pada responden Bendahara Pemerintah Daerah lingkup Pulau Jawa. Penelitian ini juga berfokus pada evaluasi Peran Direktorat Jenderal Perbendaharaan sehingga tidak memasukkan variabel Peran Direktorat Jenderal Pajak c.q. Kantor Pelayanan Pajak.

\section{PENGHARGAAN (ACKNOWLEDGEMENT)}

Penelitian ini dapat diselesaikan berkat bantuan rekan-rekan Direktorat Pengelolaan Kas Negara
DJPb, Pusdiklat Anggaran dan Perbendaharaan BPPK, Kanwil Ditjen Perbendaharaan Provinsi DKI Jakarta, Kanwil Ditjen Perbendaharaan Provinsi Jawa Barat, Kanwil Ditjen Perbendaharaan Provinsi Jawa Tengah, Kanwil Ditjen Perbendaharaan Provinsi DI Yogyakarta, Kanwil Ditjen Perbendaharaan Provinsi Jawa Timur dan Kanwil Ditjen Perbendaharaan Provinsi Banten serta pihak-pihak lain yang tidak dapat kami sebutkan satu per satu.

\section{REFERENSI}

Afni, M. (2013). Faktor-faktor yang mempengaruhi kepatuhan wajib pajak bendaharawan pemerintah di Kabupaten Rokan Hilir. (Skripsi Tidak Dipublikasikan). Universitas Islam Negeri Sultan Syarif Kasim Riau.

Asfa, E. R., \& Meiranto, W. (2017). Pengaruh sanksi perpajakan, pelayanan fiskus, pengetahuan dan pemahaman perpajakan, kesadaran perpajakan terhadap kepatuhan wajib pajak. Diponegoro Journal of Accounting 6(3), 113.

Biaya kepatuhan dan digitalisasi pelayanan (2019). Diakses 28 Agustus 2019 dari http://punditax.com/biaya-kepatuhandan-digitalisasi-pelayanan/.

Bird, R. M., \& Oldman, O. (2000). Improving taxpayer service and facilitating compliance in singapore. The World Bank Prem Note, 48 (December).

Breckler, S. J. (1984). Empirical validation of affect, behavior, and cognition as distinct component of attitude. Journal of Personality and Social Psychology. Halaman 1191-1205.

Dharma, M.T., \& Ariyanto, S. (2014). Analisis faktor-faktor yang mempengaruhi tingkat kepatuhan wajib pajak orang pribadi di lingkungan Kantor Pelayanan Pajak Pratama Tigaraksa Tangerang. Binus Business Review 5(2).

Dirjen Pajak: strategi dan capaian penerimaan pajak tahun 2018. (2018). Diakses 16 Agustus 2019 https://www.onlinepajak.com/dirjen-pajak-strategi-dancapaian-penerimaan-pajak-tahun-2018.

Fuadi, A. O., \& Yenni, M. (2013). Pengaruh kualitas pelayanan petugas pajak, sanksi perpajakan dan biaya kepatuhan pajak terhadap kepatuhan wajib pajak UMKM. Jurnal Tax \& Accounting Review Volume 1 No.1. 
Fungsi pajak. (2019). Diakses pada tanggal 16 Agustus 2019 dari https://pajak.go.id/id/fungsi-pajak.

Ghozali, I. (2016). Aplikasi analisis multivariete edisi 8. Semarang: Badan Penerbit Universitas Diponegoro.

Gujarati, D. (2003). Ekonometri dasar (Sumarno Zain, Penerjemah). Jakarta: Erlangga.

Hair et al. (2010). Multivariate data analysis, seventh edition. New York : Prentice Hall

Hardiningsih, P., \& Yulianawati, N. (2011). Faktor-faktor yang mempengaruhi kemauan membayar pajak. Jurnal Dinamika Keuangan dan Perbankan Volume 3 Nomor 1 Halaman 126 - 142.

Haq, A. A. (2017). Kedudukan dan tanggung jawab bendahara. Diakses 28 Agustus 2019 dari https://www.wikiapbn.org/ kedudukan-dan-tanggung-jawabbendahara/.

Hidayat, A. (2017). Cara hitung rumus slovin besar sampel. Diakses 20 Agustus 2019 dari https://www.statistikian.com/2017/ 12/hitung-rumus-slovin-sampel.html.

Kamil, N. I. (2015). The effect of taxpayer awarness, knowledge, tax penalties and tax authorities services on the tax compliance: (survey on the individual taxpayer at Jabodetabek \& Bandung. Research Journal of Finance and Accounting Vol 6. No 22015.

Kasiram, M. (2008). Metodologi penelitian kualitatif dan kuantitatif. Malang: UIN Maliki Press.

Komarudin. (1994). Ensiklopedia manajemen. Jakarta: Bumi Aksara.

Kurva laffer. (2019). Diakses pada tanggal 14 Agustus 2019 dari https://id.wikipedia.org/wiki/Kurva_Laff er.

Kustiawan, M., Solikin, I., \& Zulhaimi, H. (2018). Perguruan tinggi sebagai role model kepatuhan bendaharawan pemerintah dalam pemotongan dan pemungutan pajak penghasilan. Jurnal Aset (Akuntansi Riset) 10 Volume 2 Halaman 177-18.

Lee, H. C. (2016). Can electronic tax invoicing improve tax?. World Bank Group: Policy Research Working Paper Compliance.

Listyowati, S., Chomsatun, Y., \& Suhendro. (2018). Faktor-faktor yang mempengaruhi kepatuhan wajib pajak dalam membayar pajak. Jurnal Riset Akuntansi dan Bisnis Airlangga Volume 3. Nomor 1.

Mardiasmo. (2011). Perpajakan edisi revisi. Yogyakarta: Penerbit Andi.
Musgrave, Richard P., \& Musgrave, Peggy B. (1989). Public finance in theory and practice (5th ed.). New York: McGraw-Hill Book Co.

Ngadiman dan Huslin, D. (2015). Pengaruh sunset policy, tax amnesty, dan sanksi pajak terhadap kepatuhan wajib pajak (studi empiris di Kantor Pelayanan Pajak Pratama Jakarta Kembangan). Jurnal Akuntansi Vol.19 No. 2 Halaman 225-241.

Nurmantu, S. (2005). Pengantar perpajakan. Jakarta: Granit.

Pembayaran dan penyetoran pajak. (2019). Diakses pada tanggal 20 Agustus 2019 dari https://www.pajak.go.id/id/pembayaran -dan-penyetoran-pajak.

Pengamat: Penerimaan Pajak Baru 50 Persen dari Potensi (2019). Diakses pada tanggal 14 Agustus 2019 dari https://www.cnnindonesia.com/ekonomi /20190405124641-532383660/pengamat-penerimaan-pajakbaru-50-persen-dari-potensi.

Peraturan Menteri Keuangan Nomor 192/PMK.03/2007 tentang Tata Cara Penetapan Wajib Pajak Dengan Kriteria Tertentu Dalam Rangka Pengembalian Pendahuluan Kelebihan Pembayaran Pajak. Jakarta: Kementerian Keuangan.

Peraturan Menteri Keuangan Nomor 234 /PMK.01/2015 tentang Organisasi dan Tata Kerja Kementerian Keuangan. Jakarta: Kementerian Keuangan.

Peraturan Menteri Keuangan Nomor 262/PMK.01 /2016 Tentang Organisasi dan Tata Kerja Instansi Vertikal Direktorat Jenderal Perbendaharaan. Jakarta: Kementerian Keuangan.

Peraturan Menteri Keuangan Nomor 50/PMK.07/2017 Tentang Pengelolaan Transfer Ke Daerah Dan Dana Desa. Jakarta: Kementerian Keuangan.

Peraturan Pemerintah Nomor 45 Tahun 2013 tentang Tata Cara Pelaksanaan Anggaran Pendapatan dan Belanja Negara. Jakarta: Republik Indonesia.

Peraturan Pemerintah Nomor 58 Tahun 2005 tentang Pengelolaan Keuangan Daerah. Jakarta: Republik Indonesia.

PricewaterhouseCoopers. (2010). Study on the feasibility of alternative methods for improving and simplifying the collection of vat through the means of modern technologies and/or financial intermediaries.

Purwidyasari, A., \& Syafruddin, M. (2017). Analisis faktor-faktor yang mempengaruhi 

kepuasan pengguna layanan e- government: studi kasus pada modul penerimaan negara generasi 2. Diponegoro Journal of Accounting Volume 6 Nomor 4 Halaman 1-9.

Rakhmat, J. (2000). Psikologi komunikasi edisi revisi. Bandung: PT. Remaja Rosdakarya.

Ramdan, D. M. (2019). Tax ratio Indonesia rendah, ini yang harus dilakukan otoritas pajak. Diaksesl dari https://nasional.kontan.co.id/news/taxratio-indonesia-rendah-ini-yang-harusdilakukan-otoritas-pajak.

Ratnafuri, K. dan Herawati, N. (2012). Malpraktek pemotongan dan pemungutan pajak oleh bendaharawan pemerintah. Jurnal Akuntansi Multiparadigma Volume 3 Nomor 3 Halaman 471-492.

Resmi, S. (2011). Perpajakan: teori dan kasus. Jakarta: Salemba Empat.

Robbins, S. P. (2007). Perilaku organisasi buku 1. Jakarta: Salemba Empat.

Saad, N. (2014). Tax knowledge, tax complexity, tax compliance: tax payers' view. procediasocial and behavioral sciences 109 (2014). Elsevier Ltd.

Safrina, N., Julkawait \& Qalbiah, N. (2018). Account representative "dua kaki yang berdiri di dua perahu" dalam rangka pencapaian target penerimaan pajak tahun 2018 (studi kasus di Kantor Pelayanan Pajak Pratama Gresik Utara. Jurnal INTEKNA Volume 18 Nomor 2.

Santoso, S. (2016). Statistik multivariat dengan SPSS. Jakarta: Kompas Gramedia.

Sembiring, L.J. (2017). Jadi titik lemah, Sri Mulyani sebut bendahara di institusi negara sering lalai setor pajak. Diakses pada tanggal 14 Agustus 2019 dari https://economy.okezone.com/read/201 7/09/12/320/1774399/jadi-titik-lemahsri-mulyani-sebut-bendahara-di-institusinegara-sering-lalai-setor-pajak.

Setiyaji, G., \& Amir, H. (2005). Evaluasi kinerja sistem perpajakan Indonesia. Jurnal Ekonomi Universitas Indonusa Esa Unggul.

Sigit. T. A. (2019). Faktor-faktor yang memengaruhi tingkat akurasi rencana penarikan dana (RPD) harian satuan kerja kementerian/lembaga. Indonesian Treasury Review, 4(2), 145-161.

Sikap. (2019). Diakses pada tanggal 15 Agustus 2019 dari https://id.wikipedia.org/wiki/Sikap.

Soekanto, S. (2002). Teori peranan. Jakarta: Bumi Aksara.

Stiglitz, J. E. (2000). Economics of the public sector. New York: WW Norton\&Co.
Stratified random sampling: pengertian dan konsep dasar. (2018). Diakses pada tanggal 28 Agustus 2019 https://statmat.id/stratified-randomsampling-adalah.

Suandy, E. (2008). Hukum pajak edisi 4. Jakarta: Salemba Empat.

Subandi, H., \& Fadhil, M. I. I. (2018). Analisis faktor-faktor yang memengaruhi kepatuhan pajak bendahara desa di Kota Batu. Berkala Akuntansi dan Keuangan Indonesia Volume 03 Nomor 01.

Sukirno, S. (2000). Makroekonomi modern. Jakarta: PT Raja Drafindo Persada.

Sulistiyono, S. T. (2017). Menkeu keluhkan kurangnya pengetahuan pajak dari bendahara kementerian dan lembaga. Diakses pada tanggal 28 Agustus 2019 dari

https://www.tribunnews.com/bisnis/20 17/09/12/menkeu-keluhkan-kurangnyapengetahuan-pajak-dari-bendaharakementerian-dan-lembaga.

Suliyanto. (2005). Analisis Data Dalam Aplikasi Pemasaran. Bogor: Ghalia Indonesia.

Susherdianto, R. (2014). Analisis faktor-faktor yang mempengaruhi tingkat kepatuhan wajib pajak (studi WPOP yang memiliki usaha di Kota Kudus). (Skripsi Tidak Dipublikasikan). Universitas Diponegoro.

Suyapto, M., \& Lasmana, M. S. (2014). Analisis faktor-faktor yang mempengaruhi kepatuhan wajib pajak badan di Kantor Wilayah Direktorat Jenderal Pajak Jawa Timur I. Jurnal Ekonomi dan Bisnis Tahun XXIV Nomor 2.

Teori atribusi - pengertian - jenis - penerapan. (2019). Diakses pada tanggal 19 Agustus 2019 dari https://pakarkomunikasi.com/teoriatribusi.

Tucker, I. B. (2010). Survey of economics. Cengage Learning Halaman 341.

Undang-undang Nomor 1 Tahun 2004 tentang Perbendaharaan Negara. Jakarta: Republik Indonesia.

Undang-undang Nomor 28 Tahun 2007 tentang Ketentuan Umum Perpajakan.. Jakarta: Republik Indonesia.

Yilmaz, F., \& Coolidge, J. (2013). "Can E-filing Reduce Tax Compliance Costs in Developing Countries?". The World Bank Policy Research Working Paper (WPS6647). 


\section{LAMPIRAN}

\begin{tabular}{|l|l|r|r|}
\hline \multicolumn{3}{|c|}{ Iteration History ${ }^{\mathbf{a}, \mathbf{b}, \mathbf{c}}$} \\
\hline \multirow{3}{*}{ Iteration } & $\begin{array}{c}\text {-2 Log } \\
\text { likelihood }\end{array}$ & $\begin{array}{c}\text { Coefficient } \\
\text { S }\end{array}$ \\
\hline Step 0 & 1 & 1204,123 &,- 230 \\
\cline { 3 - 5 } & 2 & 1204,123 &,- 231 \\
\cline { 2 - 4 } & 3 & 1204,123 &,- 231 \\
\hline
\end{tabular}

\begin{tabular}{|c|c|c|c|c|c|c|c|c|}
\hline \multicolumn{9}{|c|}{ Iteration History $^{\mathbf{a}, \mathbf{b}, \mathbf{c}, \mathbf{d}}$} \\
\hline \multirow{2}{*}{\multicolumn{2}{|c|}{ Iteration }} & \multirow{2}{*}{$\begin{array}{l}-2 \text { Log } \\
\text { likelihood }\end{array}$} & \multicolumn{6}{|c|}{ Coefficients } \\
\hline & & & Constant & PP & SKP & KPP & KAP & PD \\
\hline \multirow[t]{8}{*}{ Step 1} & 1 & 554,187 & $-16,733$ & ,091 & ,068 & ,356 & 041 & ,032 \\
\hline & 2 & 403,371 & $-29,398$ & ,212 & ,113 & ,553 & 092 & ,035 \\
\hline & 3 & 338,432 & $-43,643$ & ,398 & 142 & ,738 & , 149 & ,026 \\
\hline & 4 & 316,119 & $-57,418$ & 608 & ,158 & ,895 &, 194 & 021 \\
\hline & 5 & 312,416 & $-65,762$ & ,741 & ,167 & ,982 & ,216 & ,023 \\
\hline & 6 & 312,283 & $-67,733$ & ,772 & ,169 & 1,003 & ,222 & ,024 \\
\hline & 7 & 312,283 & $-67,817$ & ,774 & ,169 & 1,004 & ,222 & ,024 \\
\hline & 8 & 312,283 & $-67,817$ & ,774 & ,169 & 1,004 & ,222 &, 024 \\
\hline
\end{tabular}

\begin{tabular}{|l|l|r|r|r|}
\hline \multicolumn{5}{|c|}{ Omnibus Tests of Model Coefficients } \\
\hline \multirow{2}{|c|}{} & $\begin{array}{c}\text { Chi- } \\
\text { square }\end{array}$ & df & \multicolumn{1}{c|}{ Sig. } \\
\hline \multirow{3}{*}{ Step 1 } & Step & 891,840 & 5 &, 000 \\
\cline { 2 - 5 } & Block & 891,840 & 5 &, 000 \\
\cline { 2 - 5 } & Model & 891,840 & 5 &, 000 \\
\hline
\end{tabular}

\begin{tabular}{|l|r|r|r|}
\hline \multicolumn{4}{|c|}{ Model Summary } \\
\hline Step & $\begin{array}{c}\text { Cox } \& \\
-2 \text { Log } \\
\text { likelihood }\end{array}$ & $\begin{array}{c}\text { Snell R } \\
\text { Square }\end{array}$ & $\begin{array}{c}\text { Sagerk } \\
\text { e R } \\
\text { Square }\end{array}$ \\
\hline 1 & $312.283^{\mathrm{a}}$ &, 638 &, 855 \\
\hline
\end{tabular}

\begin{tabular}{|l|c|c|c|}
\hline \multicolumn{4}{|c|}{ Hosmer and Lemeshow Test } \\
\hline Step & $\begin{array}{c}\text { Chi- } \\
\text { square }\end{array}$ & df & Sig. \\
\hline 1 & 10,995 & & 8 \\
\hline
\end{tabular}

\begin{tabular}{|c|c|c|c|c|c|}
\hline \multicolumn{6}{|c|}{ Classification Table $^{a}$} \\
\hline \multirow{3}{*}{\multicolumn{3}{|c|}{ Observed }} & \multicolumn{3}{|c|}{ Predicted } \\
\hline & & & \multicolumn{2}{|c|}{$\mathrm{KB}$} & \multirow{2}{*}{$\begin{array}{l}\text { Percentag } \\
\text { e Correct }\end{array}$} \\
\hline & & & 0 & 1 & \\
\hline \multirow[t]{3}{*}{ Step 1} & KB & To & 455 & 34 & 93,0 \\
\hline & & 1 & 34 & 354 & 91,2 \\
\hline & Ove & centage & & & 92,2 \\
\hline
\end{tabular}

\begin{tabular}{|c|c|c|c|c|c|c|c|c|c|}
\hline \multicolumn{10}{|c|}{ Variables in the Equation } \\
\hline & & \multirow[b]{2}{*}{ B } & \multirow[b]{2}{*}{ S.E. } & \multirow[b]{2}{*}{ Wald } & \multirow[b]{2}{*}{ df } & \multirow[b]{2}{*}{ Sig. } & \multirow[b]{2}{*}{$\operatorname{Exp}(B)$} & \multicolumn{2}{|c|}{ 95\% C.I.for EXP(B) } \\
\hline & & & & & & & & Lower & Upper \\
\hline \multirow[t]{6}{*}{ Step $1^{a}$} & PP & ,774 & ,112 & 47,834 & 1 &, 000 & 2,168 & 1,741 & 2,699 \\
\hline & SKP & 169 & ,057 & 8,825 & 1 & ,003 & 1,184 & 1,059 & 1,324 \\
\hline & KPP & 1,004 & ,118 & 72,874 & 1 &, 000 & 2,728 & 2,167 & 3,435 \\
\hline & KAP & ,222 & ,083 & 7,212 & 1 & ,007 & 1,249 & 1,062 & 1,468 \\
\hline & PD & ,024 & 059 & , 170 & 1 & ,681 & 1,024 & ,913 & 1,149 \\
\hline & Constant & $-67,817$ & 5,737 & 139,734 & 1 &, 000 & ,000 & & \\
\hline
\end{tabular}

